\title{
State Pollution Statutes
}

\author{
David P. Currie $\dagger$
}

The explosion of new pollution control legislation in the last few years is a familiar phenomenon. As an intimate participant in the Illinois branch of this experience, I have published a pair of articles attempting to analyze the Illinois program from the inside. ${ }^{1}$ This article is a preliminary tour of the pollution laws of other states. My hope is to expose general patterns of pollution control legislation, to offer comparative judgments, and to uncover new ideas. No pretense is made that one can adequately evaluate a pollution control program by the statutes alone. The true test lies in the performance of the administering agency. Unfortunately, the sheer size of the task precludes an investigation of agency practice in each of the fifty states. But while a sound statutory framework is no guarantee of a vigorous, reasonable program, it is an indispensable prerequisite. A study of the statutes alone may therefore be a useful first step toward understanding how well the states are doing.

The efforts to control both air and water pollution are increasingly dominated by federal statutes. ${ }^{2}$ Inadequate state authority thus does not necessarily ensure that there will be too much pollution. State efforts remain important, however. In the first place, the federal laws are not comprehensive. They are patchworks dealing with certain prominent problems, and in the areas they leave unregulated, state law is indispensable. Moreover, the federal programs attempting to alleviate air and water pollution rely heavily on state participation, through state plans for implementing fed-

$\dagger$ Harry N. Wyatt Professor of Law, The University of Chicago. Member, Illinois Air Pollution Control Board, 1969-70; Illinois Coordinator of Environmental Quality, 1970; Chairman, Illinois Pollution Control Board, 1970-72. This paper is based upon a research project undertaken by Margaret Conable, J.D. The University of Chicago 1980. My thanks also to Rodrigo Howard, of the class of 1982 , for extensive assistance in verifying the many statements of the law.

I Currie, Rulemaking Under the Illinois Pollution Law, 42 U. Chi. L. Rev. 457 (1975) [hereinafter cited as Rulemaking]; Enforcement Under the Illinois Pollution Law, $70 \mathrm{Nw}$. U.L. REv. 389 (1975) [hereinafter cited as Enforcement].

2 Federal Water Pollution Control Act, 33 U.S.C. \$§ 1251-1376 (1976 \& Supp. II 1978); Clean Air Act, 42 U.S.C. \$§ 7401-7642 (Supp. II 1978). 
eral air quality standards $s^{3}$ and state administration of the national pollutant discharge elimination system ("NPDES") for water pollution control."

This investigation is focused on laws concerned with air and water pollution. The analysis seeks to highlight important features on a functional basis, without attempting to describe the details of each state's program.

\section{Introduction: The Origins of Administrative Regulation}

The central principles governing pollution control are easily stated. If we do too little to prevent pollution, we may wipe ourselves out; if we do too much, we may go back to the Dark Ages. ${ }^{5}$ Translating these postulates into a real-life program, however, is a formidable task for the social architect, and the source of acute controversy.

\section{A. The Market}

Much travail (including this article) could be avoided if that deity of economists, The Market, could be counted on to control pollution. But even the faithful acknowledge that it cannot be. The difficulty is that much of the harm done by a polluter falls upon others. In his rational self-interest, the polluter may be willing to destroy an entire county to make an extra dime. He would not do so if the victim offered him twenty cents to stop, but in the real world the victim cannot always make the offer. In the typical pollution case, the harm is suffered not by one but by thousands. The costs of transacting with so many people will in some cases be high enough that the bargain to maximize society's wealth by reducing pollution will not be made. ${ }^{6}$ Thus, concludes the economist, if the law does not intervene there will be too much pollution.?

s 42 U.S.C. \& 7410 (Supp. II 1978).

33 U.S.C. \& 1342 (1976 \& Supp. II 1978).

- For introductory surveys of the sources, effects, and cures of air pollution, see CounCII on Environmental Quality, Environmental Quality 61-91 (1970); Note, Air Pollution: Causes, Sources and Abatement, 1968 WASH. U.L.Q. 205. For much more detailed information, see Arr Pollution (3d ed. A. Stern 1977).

- Coase, The Problem of Social Cost, 3 J.L. \& Econ. 1, 15-16 (1960).

7 There is another argument that also holds appeal for economists. In the arid western states, the traditional law of water rights, which vaguely entitled each landowner to "reasonable" use of the stream, was replaced by a rule granting the first taker a permanent right to use the water. The rationale was that some protection against losing the water to later users was necessary to encourage investment in the irrigation works indispensable to western de- 


\section{B. Private Remedies}

Travail would also be reduced if we could leave the problem to private lawsuits brought against polluters by their victims. Such suits have long been permitted, and they serve useful purposes; but they cannot suffice. We can guard against possible economic inefficiency in such actions by refusing to enjoin pollution that produces net social benefits ${ }^{8}$ and by requiring victims to take steps to minimize their losses. ${ }^{9}$ We can do away by statute ${ }^{10}$ with artificial limitations on the right of injured people to sue. ${ }^{11} \mathrm{We}$ can counter the reluctance of pollution victims to incur large litigation costs by the prospect of fat attorney's fees in a class action. Yet the ultimate inadequacy of the best private law was writ large by a class action filed not long ago on behalf of seven million residents of the Los Angeles area against 1,293 defendants, most of them unknown and unnamed, asking a court to do something to improve the air. ${ }^{12}$ The court quite properly threw its hands up and the suit out. The belief that a lawsuit is the best way to determine not only the opti-

velopment. See Moyer v. Preston, 6 Wyo. 308, 318-19, 44 P. 845, 847 (1896). The same considerations suggest the desirability of some legal assurance that expenditures to put land to beneficial use will not be rendered vain by subsequent pollution.

We have come this far without mentioning the argument that government should take action against pollution because it is wrong. Professor Coase has admonished us that one landowner injures another by preventing him from running a polluting business. Coase, supra note 6, at 2. It is likewise true that the prohibition of punching noses limits liberty, but many would find a moral basis for the philosopher's conclusion that freedom to extend the arm ends at the next person's nose. There are difficulties in distinguishing "mine" from "thine" when every action affects one's neighbor, but logic seems unlikely to overcome the widely shared view that one who throws "too much" filth upon his neighbors has done them wrong. See Epstein, Nuisance Law: Corrective Justice and Its Utilitarian Constraints, $8 \mathrm{~J}$. Legal Stud. 49 (1979). See also J. Esposito, Vanishing Air (1970). How much is too much is of course the crucial question.

- See Boomer v. Atlantic Cement Co., 26 N.Y.2d 219, 257 N.E.2d 870, 309 N.Y.S.2d 312 (1970) (semble).

- Spur Indus., Inc. v. Del E. Webb Dev. Co., 108 Ariz. 178, 494 P.2d 700 (1972), is illustrative of this general approach.

10 E.g., Мrсн. Comp. Laws Ann. \$§ 691.1201-.1207 (Supp. 1980). See Sax \& Conner, Michigan's Environmental Protection Act of 1970: A Progress Report, 70 Mich. L. REv. 1003 (1972).

12 E.g., Bouquet v. Hackensack Water Co., 90 N.J.L. 203, 101 A. 379 (1917) (riparian landowner could not maintain a public nuisance action because his injury was not shown to be different from that suffered by the public in general).

12 Diamond v. General Motors Corp., 20 Cal. App. 3d 374, 97 Cal. Rptr. 639 (Dist. Ct. App. 1971). For additional discussion of the difficulties of private actions to redress pollution, see Hines, Nor Any Drop to Drink: Public Regulation of Water Quality (pt. 1), 52 Iowa L. REv. 186, 196-201 (1966). 
mum pollution level in Los Angeles, but also who should take what steps to achieve it, is a pipe dream.

\section{Emission Charges}

A favorite refuge of those seeking to avoid the horrors of bureaucratic regulation is to make polluters consider the true costs of their actions by imposing emission charges taxing them in the amount of the harm they do to others. ${ }^{13}$ The argument is attractive. Not only will the rational polluter stop polluting before causing a net harm to society; ${ }^{14}$ taxation also serves our sense of fairness by requiring payment for using public resources-the air or the water-as a receptacle for private wastes.

The difficulty of determining the level at which emission taxes or charges should be set, however, has precluded their widespread use. In order to achieve optimal pollution control, the charge should reflect the cost of the damage done by each unit of a contaminant emitted. Quantifying pollution damage even in the gross has proved problematic for economists, however. ${ }^{16}$ The problem is exacerbated by the fact that the damage done by any given unit of contamination varies widely according to a host of factors. A stated quantity of sulfur dioxide, for example, may do no detectable harm at all if emitted in an area where there are no other emissions; yet when it is added to existing discharges of the same pollutant in a heavily contaminated area, it could mean the difference between life and death. Moreover, the identical quantity discharged may have a more acute effect on air quality, and thus do more damage, if emitted at ground level rather than through a high stack, or during calm rather than windy weather, or in a confined river valley rather than on a plain. The same quantity of hydrocarbon emissions may cause a more serious oxidant problem in Denver than in Minneapolis because of the higher altitude and greater prevalence of sunlight. Identical sulfur dioxide emissions may be more harmful in the presence of high particulate concentrations. Further, even the same levels of ambient air quality may do more harm in

13 See, e.g., A. Knegse \& B. Botgr, Managing Water Quality: Economics, TechnolOGY, INSTTTUTIONS 97-179, 237-53, 315-18 (1968).

14 The rational polluter will pay the emission charge only so long as it is less than the cost of abating the pollution. Thus, whenever the cost of abatement is less than the damage done by pollution, the rational polluter will not pollute.

1s See Ridker, Strategies for Measuring the Cost of Air Pollution, in The Economics of AIr Pollution 87 (H. Wolozin ed. 1966). 
New York City, where there are many people and much valuable property, than in an uninhabited desert. Pollution will do more harm to the elderly and ill than to healthy young adults, and least of all to those who take precautions against it. ${ }^{16}$

Given these uncertainties, any tax that is set would probably be highly arbitrary, and the likelihood that it would result in anything resembling an optimal degree of control is slim. Most legislative bodies have therefore understandably placed primary reliance on subjective but candid efforts to determine optimal levels of pollution by direct governmental prescription.

That we would have too much pollution without regulation or taxes, and that accurate taxation may be impracticable, does not prove that we should regulate. The costs of administration are an ever-present constraint upon the thoroughness of regulatory performance, and it is theoretically possible that such costs could exceed the benefits of reduced pollution. ${ }^{17}$ Given the vast potential for pollution damage, however, and the economic certainty of excessive damage in the absence of substantial government intervention, it is not to be expected that society will back off from its conclusion that regulation, despite its imperfections, is on balance likely to do more good than harm.

\section{Public Nuisance}

The decision that regulation is needed takes us only to the threshold of a myriad of refractory problems. What governmental institutions should be set up to deal with pollution?

The traditional, almost knee-jerk response of our legal system to the perception that government should act is to make something a crime. We began doing this long ago in response to the problem of pollution. Both the common law and supplementary statutes typically make air or water pollution a public nuisance, ${ }^{18}$ which the courts can either penalize or order abated upon suit by the ordinary public prosecutor. ${ }^{10}$ There is utility in such provisions: without the mounting procedural difficulties associated with class ac-

${ }^{16}$ See generally J. Esposito, supra note 7, at 9-19.

17 See Coase, supra note 6, at 18.

1s See W. Prosser, Handbook on the Law of Torts 583-91 (4th ed. 1971).

10 For instance, a 1969 Illinois statute, based upon the perceived need to supplement the work of indolent regulatory agencies, gave such powers to the state attorney general. ILL. Rev. Stat. ch. 14, I 12 (1979). 
tions, ${ }^{20}$ they make it practicable to bring to book the large polluter whose devastations are too scattered to justify a private suit.

To doubt the adequacy of public-nuisance law, however, one need only recall the private suit described above, seeking to remedy air pollution in Los Angeles. ${ }^{21}$ When the pollution problem results from the interaction of a multitude of sources, it is fantasy to suppose that substitution of the public prosecutor for the citizen plaintiff makes a court an appropriate forum. In addition, the highly technical information base necessary to the intelligent resolution of many pollution problems argues for the creation of a separate, expert staff. Moreover, in order to avoid shutting down civilization, a public nuisance law must leave it to the court to decide in each particular case whether the offending activity causes excessive harm in light of its utility. The resultant vagueness of the standard is a formidable deterrent to voluntary compliance. If one cannot be sure what the law requires until after a lawsuit, one may very well postpone large pollution control expenditures, either in the hope that they may be found unnecessary or for fear that they may be wasted if one has underestimated the requirements and is forced to start over.

\section{E. Administrative Agencies}

Considerations such as these have induced American governments to turn to separate administrative bodies invested with authority over pollution control, and, as will appear below, to entrust those administrators with rulemaking and adjudicative as well as with prosecutorial functions. State and local agencies slumbered quietly, on the whole, for many years. Around 1970, however, widespread public dissatisfaction with past control efforts triggered a wave of new and more vigorous environmental legislation. One result was the body of state statutes to which we now turn.

so See, e.g., Eisen v. Carlisle \& Jacquelin, 417 U.S. 156 (1974) (plaintiff must bear cost of individual notice to each class member); Zahn v. International Paper Co., 414 U.S. 291 (1973) (even when some class members satisfy federal minimum jurisdictional amount, no ancillary jurisdiction over other members with separate claims who do not); Snyder v. Harris, 394 U.S. 332 (1969) (no aggregation of class members' separate claims to satisfy amount requirement).

11 See text and note at note 12 supra. 


\section{RuLemaking}

\section{A. Delegation and its Limits}

One prominent defect of the public-nuisance law, as I have suggested, was its lack of prior warning to the polluter as to which preventive measures were required. Not surprisingly, one virtually universal feature of modern state pollution laws is their focus upon the development of detailed, specific standards prescribing the limits of permissible pollution for various contaminants and sources.

In devising these standards, the technical complexity of the problem argues for specialization. It would be possible in theory to leave rulemaking to the legislature, as in such other highly detailed fields as income taxation and traffic control. ${ }^{22}$ But legislators are busy generalists whose responsibility is to make the big political decisions; as the reality is that the details of a specific pollution code would be largely determined by a technical staff anyway, the nearly universal decision has been, as in many other complex fields such as railroad ratemaking, ${ }^{23}$ aircraft safety, ${ }^{24}$ and occupational health, ${ }^{25}$ to join power with responsibility and to seek a more professional product by eliminating the pretense of legislative adoption. ${ }^{28}$

1. Maine: Legislative Adoption. Maine provides an interesting exception to the prevailing pattern. The basic provisions ap-

22 E.g., Ill. Rev. Stat. ch. 951/2, if 11-100 to -1507.1 (1979).

$2 s 49$ U.S.C. $\S \S 10701-10786$ (Special Pamphlet 1979).

3449 U.S.C. $\$ \S 1301-1542$ (1976 \& Supp. I 1977).

${ }^{25} 29$ U.S.C. $\S \S 651-678$ (1976 \& Supp. II 1978).

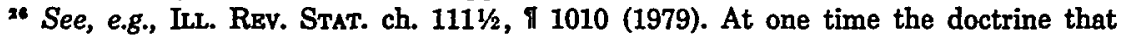
legislative power was vested in Congress and state legislatures and could not be delegated presented serious obstacles to administrative rulemaking. See A.L.A. Schechter Poultry Corp. v. United States, 295 U.S. 495 (1935). The nondelegation doctrine reflects, among other things, a constitutional policy of preserving direct popular control of lawmaking. See Zemel v. Rusk, 381 U.S. 1, 22 (1967) (Black, J., dissenting); Arizona v. California, 373 U.S. 546, 626 (1963) (Harlan, J., dissenting). The doctrine has yielded so far to the practicalities of modern government, however, that delegation of rulemaking authority will generally be upheld, at least if the legislature has laid down intelligible general principles to govern the exercise of the delegated power. See, e.g., Federal Energy Admin. v. Algonquin SNG, Inc., 426 U.S. 548 (1976). The old view still surfaces from time to time in the state courts. See, e.g., Lincoln Dairy Co. v. Finigan, 170 Neb. 777, 104 N.W.2d 227 (1960); State v. Richmond, 36 Ohio Misc. 55, 302 N.E.2d 605, 606 (Mun. Ct. 1973) (holding that environmental protection director's discretionary authority to adopt regulations "imposes on the people of this sovereign state a government by one man"), rev'd sub nom. State v. Acme Scrap Iron \& Metal, 49 Ohio App. 2d 371, 361 N.E.2d 250 (1974). In most states, however, the courts have given short shrift to delegation attacks on the pollution law. Illinois is one example. See Currie, Rulemaking, supra note 1, at 460-61. 
pear traditional enough. The Board of Environmental Protection is directed to "exercis[e] the police power of the State, to control, abate and prevent" both air and water pollution. ${ }^{27}$ To accomplish this task, the board is empowered to "adopt, amend and repeal reasonable rules and regulations necessary for the proper administration and interpretation of any provision of law that the department is charged with the duty of administering"; rules duly promulgated "shall have the full force and effect of the law."28 Other sections, however, reveal that many of the Board's most important regulations, such as air quality and emission standards, remain in effect only "until 90 days after the adjournment of the next regular or special session of the legislature,"29 unless enacted into statute. In other words, rules of these types are to be adopted by the legislature itself, not by the Board.

This is carrying mistrust of the bureaucracy to extremes. As a result the statute books in Maine are cluttered with technical details, such as a standard limiting sulfur dioxide emissions from sulfite pulping processes to " 40 pounds per air dried ton of sulfite pulp produced"30 and five pages of water quality classifications governing the Little Androscoggin River system. ${ }^{31}$ Correspondingly, there are almost no substantive regulations. ${ }^{\text {s2 }}$ For the legislature to concern itself seriously with such technicalities would take more time than it could afford and would risk serious misunderstanding of technical issues. On the other hand, if the legislature acts as a rubber stamp either for recommendations from the Board, or for politically powerful interests, legislative responsibility is a hollow pretense.

In fact the Maine statutes, despite legislative jealousy of the rulemaking power, delegate enormous discretion to the Board. Li-

${ }^{27}$ ME. Rev. Stat. Ann. tit. 38, § 361 (West 1978).

23 Id. $\S 343$.

20 E.g., id. § 584 (West Supp. 1980) (ambient air quality standards). Formerly, the agency could promulgate water classifications, although they were valid only until 90 days after adjournment of the legislature if not enacted into statute. Id. $\S 367$ (West 1978). In 1979 this authority was repealed. Now the agency may only recommend classifications to the legislature. Id. (West Supp. 1980).

so Id. § 604(2) (West 1978).

s1 Id. § 368 .

32 The only substantive regulations contained in ENv. REP., STATE WATER LAws (BNA) 796:0502-03 (1979), limit discharges of phosphorus and heat. These were adopted during a brief period when the Board enjoyed real rulemaking power, and their present validity seems highly questionable. The only air pollution regulations are procedural. See ENv. REP., State AIr LAwS (BNA) 396:0581 (1979). 
censing programs are established for sources of both air and water pollutants. Among the conditions for issuance of a license is employment of "the best practicable treatment," which the Board must essentially define for each license. ${ }^{33}$ Thus the Board apparently can avoid the necessity for legislative approval of emission standards by determining them on a case-by-case basis in processing particular permit applications.

The disadvantages of lawmaking by adjudication were well described by the Federal Trade Commission in its famous opinion justifying the rule requiring health warnings on cigarette packages. $^{34}$ In adjudication, issues affecting an entire industry are resolved without affording all those affected the opportunity to be heard. Voluntary compliance is discouraged, as under the publicnuisance doctrine, by the uncertainty of the law. Conduct undertaken in good faith may be penalized if it is later found unlawful. The same issues of practicability or harm may have to be litigated over and over again. Even the Maine legislature, by its vague definition of "best practicable treatment," has acknowledged its inability to cope with all the details of a pollution program. It should thus allow the administering agency to express its exercise of discretion through the useful tool of rulemaking.

2. Michigan: Approval by Legislative Committee. The Michigan legislature apparently mistrusts administrative rulemaking nearly as much as Maine does. Michigan's Water Resources Commission is authorized, among other things, to "establish such pollution standards for . . . waters of the state . . . as it shall deem necessary,"ss and its Air Pollution Control Commission is empowered to "establish standards for ambient air quality and emissions." Uns Under Michigan's Administrative Procedures Act, however, no permanent regulation becomes effective without the explicit approval of a committee composed of members of each house of the legislature or the passage by both houses of an ap-

3s Mr. Rev. Stat. ANn. tit. 38, § 414-A(1)(D) (West Supp. 1979) (water); id. § 582(5-A) (West 1978) (air); id. $\S 590$ (West Supp. 1979) (air). The statutes broadly define "best practicable treatment" as the treatment method that "controls or reduces emissions . . . to the lowest possible level," id. $\$ 582(5-\mathrm{A})$ (West 1978), or is "best calculated to protect and improve" water quality, id. § 414-A(1)(D) (West Supp. 1979), in both cases "consider[ing] the ... existing state of technology, the effectiveness of the available alternatives . . . and . . . economic feasibility," id. § 582(5)(A) (West 1978).

" FTC, Unfair or Deceptive Advertising and Labeling of Cigarettes, 29 Fed. Reg. 8324, 8366-68 (1964).

${ }^{25}$ Mich. Comp. Laws ANN. § 323.5 (1975).

26 Id. \& 336.15(a). 
proving resolution. ${ }^{37}$ In addition, regulations must be approved as to form by the legislative service bureau and as to legality by the attorney general..$^{38}$ The absence of any corresponding criteria for appraisal by the legislature or its joint committee implies that those bodies are to conduct a free-wheeling reexamination of the merits of proposed rules.

Any legislature that delegates rulemaking power to an administrative agency retains the right to overturn the actions of its delegate by enacting legislation. Thus there is nothing inimical to the principle of delegated power in a requirement that regulations be filed with the legislature, with a view to possible corrective legislation. ${ }^{39}$ Michigan, however, goes far beyond this. In requiring affirmative legislative approval of individual regulations, it flies in the face of the principal reason for the delegation of rulemaking power: the impracticability of thorough legislative consideration of technical and time-consuming detail.

3. Ohio: Legislative Veto. Ohio authorizes administrative adoption of a broad spectrum of regulations including water quality standards" ${ }^{40}$ and rules "for the prevention, control, and abatement of air pollution."41 But the Ohio Administrative Procedure Act provides that the legislature may invalidate any regulation by concurrent resolution, and that no regulation is effective for sixty days pending legislative review. ${ }^{42}$

In theory the grounds for legislative disapproval are limited. A joint committee is to recommend rejections only if the regulation exceeds "statutory authority," "conflicts with another rule," or "conflicts with the legislative intent in enacting the statute" under which the rule is proposed. ${ }^{43}$ Yet the statutory authority to fight pollution is broadly phrased: disagreement with the conclusion

37 Id. $\$ \S 24.245,24.235$ (Supp. 1980). There is an exception for temporary "emergency" measures, but only if the Governor certifies the existence of the emergency. Even then, the regulation may be rescinded by concurrent resolution without the opportunity for gubernatorial veto that characterizes the normal legislative process. Id. $\S 24.248$.

so Id, \& 24.245(1).

39 Washington does this. See Wash. Rev. Code AnN. § 34.04.045 (West Supp. 1980); id. § 34.04.160 (1965). See also CaL. WATER Code § 13141 (West Supp. 1979) (water quality control plans not effective until reported to legislature); MD. NAT. REs. CoDE ANN. \$ 8-1404 (Supp. 1979) (annual reports to the legislature and Governor required).

10 Ohro Rev. Code ANn. § 6111.041 (Page 1977).

${ }^{4}$ Id. \& 3704.03(E) (Page Supp. 1980).

42 Id. $\S 119.03(\mathrm{I})$. The only exception is if a gubernatorial certification of emergency exists, in which case the regulation is effective, but for only 90 days. Id. $\S 119.03(\mathrm{~F})$.

4s Id. § $119.03(\mathrm{I})(1)-(3)$. 
that a particular level of water quality is necessary to "protect[ ] the public health and welfare,"44 for example, can easily be stated as an argument that the agency has exceeded its authority or misread "legislative intent." In effect, it seems that there can be resolutions disapproving a regulation on the basis of the merits of an agency determination.

Ohio is not so restrictive as Maine or Michigan; regulations can become law without affirmative legislative action, and waiting periods for legislative repeal are not exceptional. ${ }^{45}$ What is unusual about the Ohio statutes is that a concurrent resolution is substituted for legislation in the process of disapproval, apparently circumventing the governor's power of veto. Provisions of this kind have come under serious criticism on grounds both of constitutionality and of policy. ${ }^{48}$ For purposes of this article, their principal significance is that a legislative veto reduces the power of delegated administrative lawmaking by making legislative reversal of regulations easier than it would be in the normal legislative process.

\section{B. The Scope of Rulemaking Powers}

Those legislatures that are willing to delegate rulemaking authority take varying approaches to the problem. Some rely on (at least ostensibly) broad grants of general rulemaking authority; others couple such a grant with lists of specifically authorized types of rules; and some prefer to confine the agency's powers to particularized areas.

1. General Rulemaking Authority. A number of state statutes contain broad grants of general rulemaking authority over pollution. ${ }^{17}$ One of the most sweeping is found in Kentucky, which authorizes its Department of Natural Resources and Environmen-

4Id. § 6111.041 (Page 1977).

4 Cf. 28 U.S.C. $\$ 2072$ (1976) (90-day waiting period for effectiveness of federal rules of civil procedure promulgated by the Supreme Court).

4 See, e.g., Bruff \& Gellhorn, Congressional Control of Administrative Regulation: A Study of Legislative Vetoes, 90 HARv. L. REv. 1369, 1373-75, 1378-81 (1977). Legislative vetoes may unconstitutionally evade the executive veto and invade the judicial prerogatives of statutory construction and review. They also may cause delay in rulemaking, add to the legislative workload, frustrate the procedural checks on rulemaking by opening the process to political horse trading, and complicate the interpretation of statutory intent by requiring courts to decide whether legislative inaction constitutes implicit ratification.

"7 For example, New Mexico provides for administrative adoption of "regulations to prevent or abate water pollution," N.M. STAT. ANN. \$ 74-6-4(D) (1979). Similar provisions in Alaska, Alaska Stat. $\$ 46.03 .020(10)(A)$ (Supp. 1979), and Mississippi, Miss. Codr Ann. $\S 49-17-17$ (b), (i) (Supp. 1979), apply to both air and water. 
tal Protection, with the consent of the State Environmental Quality Commission, to promulgate "any rule or regulation pertaining to the prevention, abatement, and control of existing or threatened air or water pollution, disposal of waste, control of noise, or the use of air, land, or water resources, or strip mining and reclamation."48 Such statutes provide maximum flexibility, permitting administrators to utilize whatever form of regulation may prove most appropriate to deal with an unpredictable variety of problems.

A common variant of this broad authority is illustrated by Delaware and Connecticut statutes respectively empowering an administrator to adopt regulations "to effectuate the policy and purposes of this chapter" duties." "so The breadth of such a rulemaking grant depends upon the breadth of the "policy and purposes" or "functions, powers, and duties" described elsewhere in the statute. The Delaware provisions are typically comprehensive in this respect, including "control of pollution of the land, water, underwater and air resources ... to protect the public health, safety and welfare"si among the duties of the pollution control agency. The Connecticut statute is equally broad, directing the agency to "provide for the prevention and abatement of all water, land and air pollution."

All of the foregoing examples, however, confer authority essentially to prevent "pollution." The scope of any such rulemaking power may thus be limited by a narrow definition of "pollution." These definitions also affect the breadth of statutory prohibitions against causing "pollution"; they are examined in a later section."ss

48 Ky. Rev. Stat. § 224.045(6)(b) (Supp. 1978); see id. § 224.033(17).

49 Det. Code Ann. tit. 7, \& 6010(a) (1975 \& Supp. 1978).

so Conn. Gen. Stat. Ann. \& 22a-6(1) (1977). This language, standing alone, may be subject to a crippling interpretation; past decisions have held that similar clauses confer no substantive power. See, e.g., Mobil Oil Corp. v. Federal Power Comm'n, 483 F.2d 1238, 1254-57 (D.C. Cir. 1973); New England Power Co. v. Federal Power Comm'n, 467 F.2d 425, 430 (D.C. Cir. 1972) (clauses of "implementary rather than substantive character . . . merely augment existing powers conferred upon the agency by Congress, they do not confer independent authority to act" (footnote omitted)), aff'd, 415 U.S. 345 (1974). But see National Petroleum Refiners Ass'n v. FTC, 482 F.2d 672, 678 (D.C. Cir. 1973) (authority to promulgate "rules and regulations [for the purpose of carrying out a section of the Trade Commission Act] should be construed to permit the Commission to promulgate binding substantive rules as well as rules of procedure"). The Connecticut statute, however, precludes such an interpretation by explicit reference to both "environmental standards" and "procedural regulations." Conn. Gen. Stat. ANn. § 22a-5(e) (1977).

s1 Del. Code Ann. tit. 7, § 6001(c)(2) (1975).

${ }^{32}$ Conn. Gen. Stat. Ann. \$ 22a-5(e) (1977).

ss See Part III infra. 
In some states, moreover, an ostensibly broad grant of rulemaking power is cut back by specific statutory limitations. New Mexico, for example, limits its general grant of rulemaking authority by a provision that no regulation may "specify the method to be used" to avoid pollution. ${ }^{34}$ This restriction appears to be motivated by legitimate desires to avoid monopolies and to induce dischargers to seek efficient control methods. Unfortunately, it seems to make it impossible to prescribe work practices to minimize pollution when absolute limitations on the amount of emissions are impracticable, as in the control of asbestos in the demolition of buildings. ${ }^{\text {ss }}$ Ohio, more significantly, appends to an otherwise general grant of rulemaking power the words "prescribing . . . emission standards for air contaminants, and other necessary regulations for the purpose of achieving and maintaining compliance with ambient air quality standards."Bs Perhaps it is only "other necessary regulations" that are limited to achieving ambient standards, but a comma is a weak reed in statutory construction. Even at best, the only permissible regulations independent of air quality are "emission standards."

It is common to embellish general rulemaking grants with lists of specific types of regulations intended to be included, such as explicit authorization for "standard[s] of performance for new sources," the most extensive lists is found in Nevada, which supplements a general authority with express references to "air quality standards," "emission control requirements," "fuel standards," and "elimination of devices or practices which cannot be reasonably allowed without generation of undue amounts of air contaminants." 59 The evident purpose of such additions is to guard against the risk that a court might hold the general rulemaking authority less all-inclusive than it appears. Specification in turn creates the risk that a court may invoke maxims such as inclusio unius est exclusio alterius or ejusdem generis to cut down the scope of the general grant, and of course it is impossible for a legislature to foresee and to list every type of regulation that may prove useful. ${ }^{\circ 0}$

N.M. STAT. ANN. § 74-6-4(D) (1979).

ss See 38 Fed. Reg. 8820, 8821 (1973).

s6 Ohio Rev. Code Ann. § 3704.03(E) (Page 1980).

87 N.M. Stat. ANN. \$ 74-6-4(D) (1979).

so Miss. Code ANN. \$ 49-17-17(h) (Supp. 1979).

s* Nev. Rev. STAT. § 445.461(1)-(2), (5), (8)-(9) (1979).

so One example of the incompleteness of any such list is provided by Village of Lom- 
2. Specific Provisions. Some states, either by oversight or in order to keep administrators under tighter control, avoid grants of general rulemaking power and rely entirely upon lists specifying the types of regulations that may be adopted. These lists typically include air or water quality standards and emission or effluent standards, and in some states they include nothing else. ${ }^{61}$ The obvious risk in such statutes is the omission of useful types of regulations. For instance, even if the power to adopt ambient standards implies implementing regulations directed toward dischargers, there may be a place for discharge limitations not immediately related to ambient quality. ${ }^{62}$ Moreover, it is by no means clear that a reference to "effluent" or "emission" standards embraces limitations on the composition of process materials (such as the familiar limits on sulfur in fuels or phosphate in detergents), much less the various traffic control measures commonly employed to combat ve-

bard v. Pollution Control Bd., 66 Ill. 2d 503, 363 N.E.2d 814 (1977). The Illinois Supreme Court held that the power to adopt "regulations to promote the purposes of this Title," including control of water pollution, ILL. REv. STAT. ch. 111/1/2, 1013(a) (1979), did not include regulations requiring consolidation of sewage treatment facilities. While the court purported to recognize that the statutory listing of permissible regulations was not exclusive, it seems to have been heavily influenced by the absence of this specific type of regulation from the list.

1 E.g., Indiana, which empowers its stream pollution control board only to determine what constitutes polluted water and to restrict "the polluting content" of any discharges, IND. CoDE ANN. § 13-1-3-7 (Burns 1973); Georgia, where the only regulations authorized by the water law are "effluent limitations" and "standards of water purity," GA. Code ANN. \$ 17-505 (Supp. 1980); and Kansas, which lists "ambient air quality standards" and "emission control requirements," KAN. STAT. ANN. \$§ 65-3005(K), -3010 (Supp. 1979), as the only permisgible regulations under its air statute. The Kansas and Georgia statutes contain additional provisions that arguably take them out of the category we are now discussing. The former authorizes "rules and regulations implementing and consistent with this act," id. $\S 65-3005$ (a), the latter those "necessary for the proper administration of this Chapter," GA. CoDE ANN. § 17-505(9) (Supp. 1980). But the bland wording of these general provisions and the presence of separate provisions specifying ambient and discharge standards suggest that the general language confers only procedural rulemaking authority and conveys no additional substantive powers. See note 50 supra.

62 See Currie, Rulemaking, supra note 1 , at $457,491-95$. In some places there may be so much clean air or water to dilute the discharge that ambient standards could be met without treatment. Yet ambient standards must be met in the future as well as today. "We cannot allow present emission sources to use up the entire assimilative capacity of the air without robbing the future of the opportunity for growth." Emission Standards, 4 IIl. P.C.B. 298, 309 (1972). In addition, there may be significant benefits in keeping the air or water cleaner than ambient standards. Ambient standards are based on incomplete knowledge and represent the worst level of pollution we are willing to tolerate rather than the optimum level. It may therefore be desirable to prevent areas now clear from deteriorating to the level of the ambient standard. Also, certain geographical areas may call for more protection than necessary to meet the ambient standards on account of special esthetic or recreational values. 
hicle pollution. ${ }^{6 s}$ Nor is it clear that work practice requirements are authorized as part of a power to adopt "emission standards."

There is an enormous variety of substantive regulations that are specifically authorized by one state or another. There are special provisions authorizing administrative regulation of motor vehicles, ${ }^{65}$ fluorocarbons, ${ }^{68}$ grain drying, ${ }^{67}$ particulates from the processing of agricultural products, ${ }^{68}$ forest burning, ${ }^{69}$ mercury emissions, ${ }^{70}$ and the open burning of field or turf grass for seed production $^{71}$ or for agricultural purposes in general..$^{72}$ Other laws specifically authorize regulation of coal mine leaching, ${ }^{78}$ the nutrient or phosphate level in cleaning agents, ${ }^{74}$ the testing and use of substances employed to clean up oil spills, ${ }^{75}$ and oil transfer, treatment, and disposal. ${ }^{76}$

A few states authorize the creation of permit systems by regulation; in others, permit requirements are imposed directly by statute. ${ }^{77}$

\section{Criteria to Guide Rulemaking}

Statutory guidance for administrative determination of pollution standards is often nebulously general. Often the legislature essentially directs the agency to consider both the benefits and the

\footnotetext{
as For examples of such traffic control measures, see D. CuRrie, Polnution: Cases aND Materials 363-79 (1975).

- See Adamo Wrecking Co. v. United States, 434 U.S. 179 (1978), in which the Court found one work practice requirement, the wetting of asbestos prior to building demolition, not to be an emission standard.

os ARIz. Rev. Stat. ANN. \$§ 36-1771 to -1780 (Supp. 1979); Nev. REv. Stat. § 445.610.710 (1979). Both states provide for establishment of exhaust emission standards and inspection programs.

os Mich. Comp. Laws ANN. §§ 336.101-.107 (Supp. 1980).

oz Mo. ANn. Code art. 43, \& 693(d) (1980).

as Tex. Rev. Civ. Stat. ANn. art. 4477-5, \& 3.10(e) (Vernon 1976).

6 WASH. Rev. Code ANN. $\$ \S 70.94 .660, .670$ (1975).

${ }^{70}$ Wis. Stat. ANN. $\$ \S 144.421-.423$ (West 1979).

72 Or. Rev. Stat. \$§ 468.450-.495 (1979); Wash. Rev. Code Ann. § 70.94.656 (1975).

72 Cal. Hzalth \& Safety Code $\$ 41850$ (West 1979); Colo. Rev. Stat. § 25-7-123(b) (Supp. 1979).

${ }^{73}$ PA. Cons. Stat. ANn. §§ 35.691.315, .760.1 (Purdon 1977); id. § 32.5116 (Purdon Supp. 1980).

${ }^{74}$ Mich. Comp. Laws ANN. \$§ 323.231-.236 (1975); Iowa Codg ANN. § 455B.32(4) (West Supp. 1980). The Michigan statute authorizes regulations to limit these levels but the Iowa statute only allows regulations designed to publicize them.

${ }^{78}$ CaL. WATzR CodB $\$ 13169$ (West 1971).

70 Mo. NAt. Res. Code ANn. \$§ 8-1406 to $-1411,-1417$ (1974 \& Supp. 1979). These provisions dominate the entire Maryland water pollution statute.

${ }^{77}$ See text and notes at notes 214-242 infra.
} 
costs of pollution control and then to achieve a reasonable balance between them. A typically unhelpful example is Wyoming's air pollution formulation:

(b) In recommending such standards or requirements the administrator shall:

(i) Consider all the facts and circumstances bearing upon the reasonableness of the emissions involved, including:

(A) The character and degree of injury to, or interference with the health and physical well being of the people, animals, wildlife and plant life;

(B) The social and economic value of the source of pollution;

(C) The priority of location in the area involved;

(D) The technical practicability and economic reasonableness of reducing or eliminating the pollution; and

(E) The social welfare and aesthetic value.

(ii) Grant such time as he shall find to be reasonable and necessary for owners and operators of air contaminant sources to comply with applicable standards or requirements. ${ }^{78}$

Other statutes instruct rulemakers to achieve standards necessary to "a reasonable balance between total costs to the people and to the economy, and the resultant benefits to the people";" to "deal with any matters deemed necessary and feasible for protecting the environment or the health of the state";80 or "to maintain the purity of the air resource of the state, which shall be consistent with protection of the public health and welfare and the public enjoyment thereof, physical property and other resources, flora and fauna, maximum employment and full industrial development of the state."81

78 Wyo. Stat. § 35-11-202 (1977).

78 Iowa Code ANn. $\$ 455 B .35$ (West Supp. 1980).

so IDAHO Code \& 39-107(8) (Supp. 1980).

81 IND. CoDE ANN. \& 13-1-1-1 (Burns 1973) (optimistically stating the competing considerations as absolutes); see id. § 13-1-1-4(3). See also S.D. Codrted LAws ANN. § 34-2-11 (1977) (water quality standards shall "protect the public health and welfare and the present and prospective use of such waters for public water supplies, propagation of fish and aquatic life and wildlife, recreational purposes and agricultural, industrial and other legitimate 
Some statutes give even less guidance. For example, in South Dakota the only criteria limiting an agency in setting effluent standards are that they must "include as a minimum all categories for which the federal government has set standards" and "be at least as stringent" as the federal standards. ${ }^{82}$ Presumably the board is to attempt to carry out in its regulations the state's general statutory policy "to conserve the waters of the state and to protect, maintain and improve the quality thereof" for a variety of named uses; ${ }^{83}$ the explicit inclusion of "agricultural, industrial, . . . and other legitimate uses"84 ensures that the utility of water as a vehicle for waste disposal will be given consideration. Rhode Island, probably the extreme example of standardless delegation, simply authorizes agency adoption of "standards of water quality" and "reasonable rules and regulations for the prevention, control and abatement of [water] pollution," without so much as a declaration of statutory policy. ${ }^{85}$

Any of the above formulations obviously leaves a great deal to the judgment of the agency. This latitude is consistent with the initial legislative decision that the subject is too complex and technical to make close legislative scrutiny practicable.

Sometimes, however, the statutory requirements are more confining. New Mexico, for example, authorizes "a standard of performance for new sources which reflects the greatest degree of effluent reduction . . . achievable through application of the best available demonstrated control technology, processes, operating methods, or other alternatives." ent limitations require at least "effective secondary treatment" of all sanitary sewage before discharge. ${ }^{87}$ Maryland generally insists that state and federal air quality standards be "identical" and that emission standards be "no more restrictive than required to attain and maintain the ambient air quality standards," except where other federal standards are more stringent. ${ }^{88}$ Massachusetts re-

uses").

s2 S.D. CoDIrIED LAwS ANN. \$ 34A-2-13 (1977). The agency must perform the usual balancing act to set ambient standards, see id. $\$ 34 \mathrm{~A}-2-11$, quoted in note 81 supra.

s S.D. Codified Laws ANN. § 34A-2-1 (1977).

84 Id.

25 R.I. Gen. Laws § 46-12-3 (1971).

s6 N.M. Stat. ANN. § 74-6-4(D) (1979).

${ }^{87}$ N.Y. Envir. Conserv. Law § 17-0509 (McKinney Supp. 1979).

s MD. ANn. CoDE art. 43, § 693(b)(3), (6) (Supp. 1979). On request of local authorities, however, stricter standards may be set. Id. $\S 693(\mathrm{~b})(2)$. 
quires its administration, in adopting initial amendments to its implementation plan, to "postpone the achievement dates for the primary and secondary ambient air quality standards to the latest dates permitted pursuant to federal law."89

The dominant theme in all of these more explicit requirements, however, is to conform state standards to the federal. The common insistence that state standards be no less exacting than federal requirements ${ }^{90}$ is a predictable response to the availability of federal grants for agencies that qualify to help administer the federal program. ${ }^{91} \mathrm{~A}$ state's willingness to be a party to enforcing regulations it has not determined to be reasonable seems highly questionable policy, yet a refusal to go along would leave the affected polluter subject to federal enforcement and thus accomplish little. More difficult to comprehend is the not infrequent command, as exemplified by the Massachusetts and Maryland statutes just quoted, to be no more stringent than federal law. Federal requirements may well be excessively demanding in some instances, but there is no reason to expect that standards expressing a nationwide minimum of pollution control will suffice for every case and all extraordinary needs. It is bad enough that Congress all too often forbids the states to adopt standards to protect their own people; 92 for a state voluntarily to abdicate its own responsibility in this manner is to punish the people in a fit of pique.

\section{Rulemaking Procedure}

Most states require "public hearings" before the adoption of substantive regulations. A typical statute provides for the promulgation of environmental standards "after proper study and after conducting a public hearing upon due notice."

In some states the hearing requirement is subject to exceptions or qualifications. Colorado requires hearings only in connection with some of the authorized regulations. ${ }^{94}$ In Kentucky hearings are held before an advisory committee that summarizes public

89 Mass. AnN. Laws ch. 111, § 142(D) (Michie/Law. Co-op 1975).

20 E.g., S.D. Codiried Laws ANN. § 34A-2-13 (1977).

${ }^{21}$ See 33 U.S.C. \$§ 1255, 1256, 1281 (1976); 42 U.S.C. § 7405 (Supp. II 1978).

${ }^{92}$ E.g., 42 U.S.C. \& 7543(a) (Supp. II 1978) (prohibiting state emission standards for new motor vehicles). See Currie, Motor Vehicle Air Pollution: State Authority and Federal Pre-Emption, 68 Mich. L. Rev. 1083 (1970).

93 S.C. CODE § 48-1-60 (1977).

24 Colo. Rev. Stat. $\S \S 25-8-205,-402$ (1974 \& Supp. 1979), which requires hearings to set water quality standards but not to promulgate other regulations. 
response for the agency that actually promulgates rules.95 In Alaska, while public proceedings are open to all interested parties, oral statements may be limited at the discretion of the department. $^{.6}$

Other states weaken their hearing requirements by providing for less than comprehensive notice to the public. In Nevada notice of the required hearing must be published only if "the regulation provides a standard of water quality or waste discharge," and then only "in a newspaper of general circulation in the area to which the standard . . . will apply." ${ }^{\prime 97}$ If the commission does no more than this, many interested people will have no notice at all. New York's water law demands a somewhat more sincere effort to provide a meaningful hearing, by requiring notice by mail to "such other persons as the department has reason to believe may be affected by the proposed standards."98

The Georgia and Kansas water pollution statutes contain no provision for public participation in the adoption of regulations. ${ }^{90}$ Fortunately, the omission is remedied by general statutes requiring notice and a hearing before any state agency promulgates regulations. ${ }^{100}$ Government in the dark comports poorly with the appearance of government for the people, and it creates serious risks of error. Whether oral statements of position really add enough to justify their inefficiency may be doubtful, ${ }^{101}$ but at the least the states ought to disseminate broadly both the terms of and the justification for a proposed regulation, and solicit written responses. ${ }^{102}$

os Ky. Rev. Stat. Ann. § 224.045(6) (Baldwin Supp. 1978).

* Alaska Stat. \$ 44.62 .210 (1976).

$\because$ Nev. REv. StAt. \& 445.207 (1977).

" N.Y. Envir. Conserv. LAW § 17-0301(10)(b) (McKinney 1973).

- GA. Code AnN. \$§ 17-501 to -530 (1971 \& Supp. 1979); KAN. Stat. AnN. §§ 65-161 to -771 (Supp. 1979).

100 Ga. Codr Ann. § 3A-104 (Supp. 1979); Kan. Stat. Ann. § 77-421 (Supp. 1979).

101 Oral statements of position have symbolic value in giving citizens a sense of participation through the opportunity to speak to the rulemaker face to face. Such statements may also satisfy the fear that a written statement may either not be read or not be given sufficient attention. On the other hand, there is no assurance that the rulemaker will listen at all, let alone more carefully than he would read a written submission. See Currie, Rulemaking, supra note 1 , at $469-73$.

102 This procedure was used by the Environmental Protection Agency in promulgating effluent limitation guidelines under the Federal Water Pollution Control Act. The agency characterized the process as "essential" to the promulgation of "sound" regulations. 38 Fed. Reg. 21202 (1973). See Williams, "Hybrid Rulemaking" Under the Administrative Procedure Act: A Legal and Empirical Analysis, 42 U. CHI. L. Rev. 401, 448-51 (1975). See also Currie, Rulemaking, supra note 1, at 469-73 (describing the procedures used by the Illinois Pollution Control Board). 


\section{Nuisance Provisions}

The heart of any program for administrative control of pollution is a delegation of authority to adopt regulations defining acceptable contaminant levels and practices. But no administrator will be able to foresee and to provide in advance for all possible pollution problems. Many legislatures accordingly have also enacted provisions outlawing "pollution" generally. The Nebraska Environmental Protection Act is representative:

It shall be unlawful for any person . . . [t]o cause pollution of any air, waters or land of the state or to place or cause to be placed any wastes in a location where they are likely to cause pollution of any air, waters or land of the state . . . . ${ }^{103}$

In many states, however, pollution control programs lack a catchall provision of this kind. ${ }^{104}$ Moreover, Montana and South Dakota, while purporting to outlaw all water pollution, define it as contamination in excess of that permitted by the regulations. ${ }^{105}$ This approach wholly fails to meet the need to control discharges that fall outside existing regulations. In some states, independent public-nuisance statutes may help to fill the gap. ${ }^{108}$ Alternatively, it may be possible for the administering agency to promulgate a general prohibition against "pollution" under a broad grant of rulemaking authority. ${ }^{107}$ Determining the true scope of a general ban on pollution thus requires a close examination of the terms used to define the ban.

103 Neb. Rev. Stat. § 81-1506 (Supp. 1978).

104 See, e.g., ARIz. Rev. Stat. Ann. §§ 36-770 to $-971,-1700$ to -1780 (1974 \& Supp. 1979); Kan. Stat. Ann. \$§ 65-3001 to -3023 (1972 \& Supp. 1979); Mrch. Comp. Laws AnN. $\S \S 336.11-.36$ (1975 \& Supp. 1979); Minn. STAT. ANN. §§ 115.01-.09, 116.01-.41 (West 1977 \& Supp. 1979); Mo. ANn. Stat. \$§ 203.010-195 (Vernon 1972 \& Supp. 1980); Mont. Rev. Codes ANn. $\$ \S 75-2-101$ to -429 (1979); Nev. Rzv. Stat. $\$ \S 445.131-.354, .401-.710$ (1979); N.M. Stat. ANn. §§ 74-1-1 to -10, 74-6-1-13 (1979); Utah Code ANn. \$§ 26-24-1 to -26 (1978) (air); VT. Stat. ANN. tit. 10, §§ 551-572 (1973); VA. CoDE §§ 10-17.9:1-.23 (1978 \& Supp. 1980).

${ }^{105}$ S.D. Codified Laws ANn. $§ 34$ A-2-2(1), 34A-2-21 to -23 (1977); Mont. Rev. Codes ANN. §§ 75-5-103(5), -605 (1979).

106 E.g., UtAh Code ANN. § 76-10-801 to -807 (1978).

${ }^{107}$ This occurred with respect to noise pollution in Illinois, where the Pollution Control Board promulgated its own general nuisance provision. See Currie, Rulemaking, supra note 1 , at 463-64. Such action in reliance on the general rulemaking authority, however, is vulnerable to the charge that the legislature, by refusing to enact a statutory nuisance provision, has determined that the agency should proceed only by adopting specific numerical regulations. 


\section{A. The Interests Protected}

Not all the existing statutory "pollution" prohibitions are comprehensive. Nebraska, for instance, defines air pollution as concentrations "injurious to human, plant, or animal life, or property, or the conduct of business." 108 This formulation at least arguably excludes mere interference with the quality of life.

More comprehensive, and fairly typical, are the following. Connecticut defines air pollution as

the presence in the outdoor atmosphere of one or more air pollutants or any combination thereof in such quantities and of such characteristics and duration as to be, or be likely to be, injurious to public welfare, to the health of human plant or animal life, or to property, or as unreasonably to interfere with the enjoyment of life and property. ${ }^{108}$

The Washington definition of water pollution is:

such contamination, or other alteration of the physical, chemical or biological properties, of any waters of the state, including change in temperature, taste, color, turbidity, or odor of the waters, or such discharge of any liquid, gaseous, solid, radioactive, or other substance into any waters of the state as will or is likely to create a nuisance or render such waters harmful, detrimental or injurious to the public health, safety or welfare, or to domestic, commercial, industrial, agricultural, recreational, or other legitimate beneficial uses, or to livestock, wild animals, birds, fish or other aquatic life. ${ }^{110}$

Both of these formulations appear sufficiently broad in terms of the interests they protect. "Legitimate beneficial uses" and "the enjoyment of life or property" appear to be all-embracing even without the additional interests listed for good measure. Obviously, however, the breadth of protection actually afforded by this type of statute depends upon subsidiary definitions of terms such as "pollutants" and "waters."

\section{B. The Pollutants Included}

Most states appear to define "pollutant" or "contaminant"

${ }^{108}$ NEB. ReV. StAT. \& 81-1502(2) (1976).

109 Conn. Gen. Stat. ANN. § 19-505 (West 1977).

110 Wash. Rev. Code AnN. $\$ 90.48 .020$ (Supp. 1979). 
rather broadly. For example, Washington's references to "physical, chemical or biological" alteration and to "any liquid, gaseous, solid, radioactive, or other substance" seem to leave very little room for accidental omission. Hawaii uses "substances" in its air pollution definition, coupled with a list that is expressly not exclusive: "smoke, charred paper, dust, soot, grime, carbon, noxious acids, fumes, gases, odors, particulate matter, or any combination of these."111

Some states go to great lengths in their desire to be inclusive. The Georgia law, classifying "solid or liquid particulate matter, dust, fumes, gas, mist, smoke, or vapor or any matter or substance either physical, chemical, biological, radioactive . . . or any combination or [sic] any of the above" as air contaminants, ${ }^{112}$ seems a needlessly obscure way to refer to anything solid, liquid, or gaseous. Ohio defines water pollution as "the placing of any sewage, industrial waste, or other wastes in any waters of the state" and then provides definitions of the key terms: "sewage" is any substance containing "discharge[s] from the bodies of human beings or animals"; "industrial waste" comes from "any process of industry, manufacture, trade, or business, or from the development, processing or recovery of any natural resource"; "other wastes" are "garbage, refuse, decayed wood, sawdust, shavings, bark, and other wood debris, lime, sand, ashes, offal, night soil, oil, tar, coal dust, or silt, [and] other substances that are not sewage or industrial waste."11s The point of all this specification is unclear; the final reference to "other substances" appears to make the rest redundant.

Doubtful cases under general references to "substances" or to "liquid, gaseous, and solid" matter include odors, radiation, and thermal pollution. In some cases, special provision is made for these problem areas. ${ }^{114}$ A court not disposed to sabotage the evidently all-encompassing legislative intent, however, can easily reason that odors are smelly molecules, that radiation is radioactive particles, and that thermal pollution is usually the addition of hot water. Amending the definition of pollutants to include a reference to energy would help to avoid possible oversights.

111 Hawail Rev. Stat. § 342-21 (1976).

112 GA. Code Ann. § 43-2704(1)(a) (Supp. 1979).

113 Ohio Rev. Code AnN. \& 6111.01 (Page 1977).

114 E.g., Ind. Code ANn. $\S 13-1-3-16$ (Burns 1973); Miss. Code Ann. § 49-17-5(f) (Supp. 1979). 
Sometimes there are explicit omissions from the definition. Some states exclude steam and water vapor, ${ }^{115}$ apparently ignoring the possibility that manmade fog might interfere, for example, with transportation. The "application of any materials to land for agricultural purposes or run-off of such materials from such application" and "[t]he excrement of domestic and farm animals defecated on land or run-off therefrom into any waters of the state"116 are excepted from the Ohio definition.

\section{The Resource Protected}

Connecticut's reference to "the outdoor atmosphere"117 is fairly common; a number of states employ similar language to avoid conflict with industrial hygiene and "Clean Indoor Air" statutes. 118 "Air" and "atmosphere" are used interchangeably to denote the resource being protected. Either term appears to be suffciently inclusive.

The definitions of "waters" are more variable. Some are very general, like the Louisiana statute, which includes "rivers, streams, lakes, groundwaters, and all other water courses and waters within the confines of the state, and all bordering waters and the Gulf of Mexico."119 The definitions, however, may leave three critical questions unresolved: whether "waters" include those underground, those privately owned, or those artificially created. Some statutes explicitly include all three categories. ${ }^{120}$ Others make express exceptions. Cooling reservoirs, sewers, and treatment plants are frequently excluded, ${ }^{121}$ for reasons that are obvious. One does not wish to outlaw the cleaning of polluted water prior to its discharge.

118 E.g., Utah Code ANn. § 26-24-2(1), (3) (1976); Wyo. Stat. § 35-11-103(b)(i) (1977).

116 Ohio Rev. Code Ann. $\$ 6111.04$ (C), (D) (Page Supp. 1979).

117 Conn. Gen. Stat Ann. \& 19-505 (West 1977), quoted in text at note 109 supra.

110 See, e.g., Minn. Stat. AnN. § 116.06(3) (West 1977) (defining "air pollution" as contamination of "outdoor" air). See also id. $\$ \$ 144.411-.417$ (West Supp. 1979) (Clean Indoor Air Act).

110 La. Rev. Stat. ANn. § 30:1093(5) (West Supp. 1980).

130 Alaska Stat. $\$ 46.03 .900(22)$ (1977); Ariz. Rev. Stat. Ann. § 36-1851(16) (Supp. 1979) (adding, apropos of the state's desert character, that waters "perennial or intermittent" also are included); ARK. Stat. ANN. § 82-1902(9) (1976); Conn. Gen. Stat. ANn. § 2554(b) (West Supp. 1980); IDaho Code § 39-103(9) (Supp. 1980); Ill. Rev. Stat. ch. 11111/2, 1 1003(o) (1979); Iowa Code Ann. $\$ 455 B .30(9)$ (West Supp. 1979); Minn. Stat. Ann. § 115.01(9) (West 1977); Neb. Rev. Stat. \& 81-1502(21) (1976); N.C. Gen. Stat. § 1413.213(20) (1978); S.C. Code § 48-1-10(2) (1977); S.D. CodIfIEd LAws ANN. § 34A-2-2(6) (1977).

121 Colo. Rev. Stat. § 25-8-103(16) (1974); Hawair Rev. Stat. § 342-31 (1976); OkLa. Stat. ANN. tit. 82, § 926.1(6) (West Supp. 1979); W. VA. Code § 20-5A-2(e) (Supp. 1980). 
Another common exemption is for waters on private land that do not "effect a junction with natural . . . waters,"122 especially where there is a single owner. ${ }^{123}$ The exclusion apparently is based on the theory that in that case no one is hurt but the polluter himself. Some states go even further, and exempt all privately owned ponds, ${ }^{124}$ farm ponds, ${ }^{125}$ or landlocked private surface waters. ${ }^{126}$ One danger in this type of exemption is that pollution of private waters may affect public waters with which they connect, but a properly worded prohibition on the pollution of public waters might prevent that. A more important objection to any exclusion of privately owned waters is that some states that have such exemptions appear to make no effort to protect part-owners from depredations by their fellows. ${ }^{127}$

Artificial waters do not appear to have been specifically exempted by any state, but statutes silent on the subject ${ }^{\mathbf{1 2 8}}$ are susceptible to narrow interpretation. Apart from the independent issue of private ownership, there is no obvious reason to think there is less need to protect the quality of artificial than of natural waters.

The importance of protecting groundwater should be obvious, and almost all states specifically include it in the definitions of state waters. ${ }^{120}$ Some states even go so far as specifically to ban all

${ }^{222}$ N.Y. EnviR. ConSERv. LAW \& 17-0105(2) (McKinney 1973); accord, N.D. CENT. Code § 61-28-02(6) (Supp. 1979); Ohio Rev. Code Ann. § 6111.01(H) (Page 1977); OR. Rev. Stat. § 468.700(8) (1979); Tenn. Code Ann. § 70-326(cc) (Supp. 1979). See also ME. Rev. StAT. ANN. tit. 38, § 361-A(7) (1978) (language to same effect); N.M. STAT. ANN. § 74-6-2(G) (1977) (same).

${ }^{123}$ Fla. Stat. Ann. § 403.031(3) (West 1973); Ga. Code Ann. § 17-503(d) (Supp. 1979); Me. Rev. Stat. Ann. tit. 38, § 361-A(7) (1978); Mo. AnN. Stat. § 204.016(15) (Vernon Supp. 1980) (excluding waters on private land owned by tenants in common); TENN. Code ANN. § 70-326(cc) (Supp. 1979). See also WIs. Stat. ANN. § 147.015(13) (West 1974) (excluding waters owned by "a person"-a term defined by $i d$. $\S 147.015(1)$ to include, inter alia, a municipal corporation).

${ }^{124}$ IND. CodE ANN. § 13-1-3-16 (Burns 1973).

${ }^{125}$ W. VA. Code $\S 20-5 A-2(e)$ (Supp. 1979).

126 Miss. Code ANN. § 49-17-5(f) (Supp. 1979).

${ }^{127}$ E.g., IND. Code ANn. $§ \S 13-1-3-1$ to -16 (Burns 1973).

${ }^{128}$ E.g., Colo. Rev. Stat. § 25-8-103(16) (1974); Ded. Code Ann. tit. 7, § 6002(7), (22) (1975); Hawain Rev. Stat. § 342-31 (1976); Ind. Code Ann. § 13-1-3-16 (Burns 1973); Me. Rev. Stat. Ann. tit. 38, § 361-A(7) (West 1978); Mass. Ann. Laws ch. 21, § 26A (Michie/ Law. Co-op Supp. 1980); Mo. Ann. Stat. $\$ 204.016(15)$ (Vernon Supp. 1980); Monr. Rev. Codes Ann. § 75-5-103(9) (1979); N.H. Rev. Stat. Ann. § 149.1(V), (VII) (1978); N.M. Stat. Ann. § 74-6-2-(G) (1979); Tenn. Code Ann. § 70-326(cc) (Supp. 1979); Vt. Stat. Ann. tit. 10, § 1251(7) (1973); VA. Code \& 62.1-10(a) (1973); Wyo. StAT. § 35-11-103(c)(vi) (1977).

${ }^{129}$ E.g., Cal. Watra Code $§ 13050$ (West 1971); Colo. Rev. Stat. § 25-8-103 (1974); Fla. Stat. AnN. § 403.031 (West 1973); Mo. Ann. Stat. $\$ 204.010$ (Vernon 1972). 
pollution of either surface or ground waters, rather than banning pollution of water generally and including ground waters within the definition. ${ }^{130}$ These are wise precautions, because a definition merely listing such terms as "rivers, lakes, and streams" would invite the unfortunate invocation of ejusdem generis to exclude groundwater. Rhode Island, to its serious detriment, flatly limits its definition to surface waters. ${ }^{131}$

\section{The Relevance of Cost, Intent, and Negligence}

The Connecticut statute quoted above is typical in defining air pollution as "unreasonabl[e]" interference with the enjoyment of life and property. ${ }^{132}$ Such language should make it clear that the prohibition is not absolute. Commendably, the cost of abatement is to be balanced against the harm caused by contamination. Many pollution provisions, however, are not so restrained. West Virginia, for example, forbids any discharge into the air that "would interfere with the enjoyment of life or property."1ss In water pollution statutes, absolute terminology such as Washington's prohibition of anything "harmful . . . to . . . legitimate beneficial uses" is standard..$^{134}$ Even Connecticut's air statute appears to impose an absolute ban on emissions harmful to "health" or to "property" as contrasted with their "enjoyment." Furthermore, the inclusion of "public welfare" in the category of interests absolutely protected may subsume "enjoyment" cases and render the unreasonableness clause irrelevant. Moreover, in Illinois the state supreme court construed the term "unreasonably" in a definition generally similar to Connecticut's to mean "substantial."135 In all these instances the definition of pollution is so broad that it creates the risk that million-dollar enterprises may be shut down to avoid trivial harm.

Many statutes, however, provide relief for such cases through variance or enforcement provisions expressly acknowledging the

130 E.g., Del. Code ANs. tit. 7, § 6003(a) (1974).

191 R.I. GEN. LAws \$ 46-12-1 (1971). Vermont also defines "waters" to mean surface waters only. VT. STAT. ANN. tit. 10, § 1251(7) (1973). It adds a separate provision, however, directing its agency to control "groundwater resources," although it does not define the term. Id. §§ 1278-1279 (Supp. 1980).

132 Conn. Gen. Stat. ANN. $\$ 19-505$ (West 1977), quoted in text at note 109 supra.

13s W. VA. CODE \& 16-20-2 (1972).

136 Wash. Rev. Code ANN. § 90.48.020 (Supp. 1980).

1s6 Processing \& Books, Inc. v. Pollution Control Bd., 64 Ill. 2d 68, 77, 351 N.E.2d 865, 869 (1976) (construing Ill. Rzv. STAT. ch. 1111/2, § 1003(b) (1979)). 
relevance of cost. ${ }^{136}$ In other states, industry has escaped a general shutdown despite apparently absolute provisions, presumably through the exercise of prosecutorial discretion. Unbridled discretion, however, invites abuse; it would be preferable explicitly to make consideration of abatement costs necessary in determining the existence of a violation. Care should be taken, however, to place the burden of cost justification on the polluter, who has better access to information about his own costs. The insertion of "unreasonable" or the like in the definition of pollution has an unfortunate tendency to lead to a requirement that the plaintiff show that the costs are not excessive before a violation will be found. ${ }^{137}$

The typical statute does not require that the pollution be intentionally or negligently caused in order to constitute a violation. ${ }^{138}$ There are some exceptions to this general pattern. Arkansas prohibits only knowing pollution of waters, ${ }^{139}$ providing no incentive to take precautions against accidental spills. Tennessee more reasonably excepts only "unavoidable accident,"140 thus preserving the incentive. In practice, the effect of a provision allowing consideration of abatement costs may be equivalent to a requirement of negligence. ${ }^{141}$

\section{E. Actual and Threatened Pollution}

A final dimension of these general pollution bans is that they often lack any prophylactic clause enabling the state to prevent prospective pollution. For example, Nebraska's provision makes it unlawful only to "cause" pollution;"142 except under a separate provision limited to "emergenc[ies],"14s no complaint may be issued until a violation already "has occurred."144 The problem may be alleviated in Nebraska by a broad prohibition on construction or operation of any emission source without a permit from the state

1s8 E.g., Ala. Code AnN. § 22-28-13 (1977); Cal. Health \& SafeTy Code $\$ 42352$ (1979); Del. Code Ann. tit. 7, § 6011 (1975); Hawail Rev. Stat. § 342-7 (1976); Ill. Rev. Stat. ch.

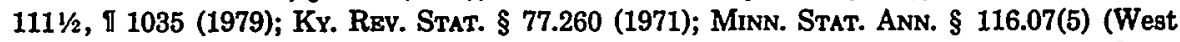
1977); Nev. Rev. Stat. \& 445.506 (1979); N.M. Stat. AnN. § 74-2-8 (1977); Ohio Rev. Code AnN. § 3704.03(H) (Page Supp. 1980); Or. Rev. Stat. § 468.345 (1979).

137 See Currie, Enforcement, supra note 1, at 460-63.

138 See, e.g., N8B. Rev. STAт. \& 81-1506 (Supp. 1978), quoted in text at note 103 supra.

139 ARK. Stat. AnN. \& 82-1938(a) (1976).

140 Tenn. Code AnN. \$ 70-336 (Supp. 1979).

${ }^{141}$ See Currie, Enforcement, supra note 1, at 407-11.

${ }^{142}$ Neb. REv. STAT. $\$ 81-1506$ (Supp. 1978), quoted in text at note 103 supra.

143 Neb. Rev. Stat. § 81-1507(4) (1976).

144 Id. § 81-1507(1). 
pollution control agency, ${ }^{145}$ coupled with a provision directing the agency to issue a prohibitory order if it determines that a permit applicant will not conform to the statute. ${ }^{146}$ The Connecticut and Washington definitions of "pollution" quoted above ${ }^{147}$ permit a certain degree of prediction as to the effect of a discharge by including conditions "likely to be" harmful. Yet these definitions still require that the discharge itself begin before legal action can be taken. It would be preferable to prohibit the threat as well as the actual occurrence of pollution. ${ }^{148}$

\section{VARIANCES}

Regulations that are reasonable for most polluters may impose unjustifiable burdens on individual firms because of special circumstances. It is therefore common in pollution control statutes, as in zoning laws, to provide a safety valve in the form of "variances," "exemptions," "waivers," "suspensions," or "temporary permits" allowing deviations from generally applicable requirements. ${ }^{149}$

Idaho, Mississippi, New Jersey, New York, and Wisconsin make no explicit provision for variances in either their air or water pollution statutes; ${ }^{180}$ many other states make no provision for water pollution variances. ${ }^{151}$ Theoretically, this is a grave oversight that could unjustly force a firm out of business. Yet the substantive equivalent of a variance may often be possible under statutory enforcement provisions. An agency that finds a violation is to issue "such . . . order . . . as it shall deem appropriate under the circumstances" in Idaho; 182 "such order as . . . will best further the purposes" of the statute in Mississippi; ${ }^{183}$ and an order to comply

14 Id. § 81-1506(2) (Supp. 1978).

16" Id. \$ 81-1506(3). Unfortunately, the order is to prohibit only "construction, installation or establishment" of the source; the section seems not to apply to existing sources.

117 See text at notes 109-110 supra.

14 See Currie, Enforcement, supra note 1, at 402-03.

14. For examples, see text and notes at notes 158-192 infra.

160 IDAно CODE $\$ \S 39-101$ to -119 (1977 \& Supp. 1979); Miss. Code ANN. $\$ \S 49-17-1$ to -43 (1973 \& Supp. 1979); N.J. STAт. ANN. §§ 26:2C-1 to -36 (West 1964 \& Supp. 1980) (air); id. \$\$ 58.10A-1 to -14 (West Supp. 1980) (water); N.Y. EnvIR. Conserv. LAw \$\$1-0101 to 19-0711 (McKinney 1973 \& Supp. 1979); Wis. Stat. ANN. \$§ 144.30-.57 (West 1974 \& Supp. 1978) (air); id. \$§ 147.01-.30 (water).

181 See, e.g., Colo. Rgv. Stat. \$§ 25-8-101 to -612 (1974 \& Supp. 1978); Nev. Rgv. Stat. $\S \S 445.131-.354$ (1979).

182 IDAHO CODE § 39-108(4) (1977).

163 Miss. Code ANN. § 49-17-31(b) (Supp. 1979). 
within a "reasonable specified time" in New Jersey. ${ }^{164}$ Hardship could lead an agency to mitigate the literal requirements of the applicable standards under any of these provisions. New York explicitly requires its pollution control agency to consider "the adequacy and practicability of various means of complying" and the polluter's "financial ability" to do so; if that consideration leads to the conclusion that "immediate compliance would be impossible or impractical," the polluter is to be given a "reasonable time" to take "the required steps."165 It seems likely that in other states, prosecutorial discretion will fill the need for flexibility. ${ }^{156}$ Again, such discretion invites abuse. Additionally, an explicit variance procedure offers significant practical advantages: an advance determination of legality so that the discharger need not violate the rules to find out his rights, and a public proceeding permitting presentation of conflicting views and ensuring public evaluation of administrative decisions. ${ }^{157}$ Some type of variance mechanism is therefore highly desirable.

\section{A. The Enabling Clause}

Many of the states that authorize variances have basic provisions similar to Alabama's: "The commission may grant individual variances beyond the limitations prescribed in this chapter whenever it is found, upon presentation of adequate proof, that compliance with any rule or regulation, requirement or order of the commission would impose serious hardship without equal or greater benefits to the public . . . " Iss In short, the commission is to balance the costs and benefits of compliance. ${ }^{159}$

Common phrases such as "serious hardship without equal or

154 N.J. Stat. ANn. \& 6:2C-14 (West 1973).

165 N.Y. Envir. Conserv. Law \& 19-0509(3) (McKinney 1973).

${ }^{186}$ It did so in Illinois before there was a provision for water variances. See Act of July

12, 1951, 1951 Ill. Laws 1462 (repealed 1970).

${ }^{157}$ See Currie, Enforcement, supra note 1, at 468-69.

13s ALA. Code § 22-28-13(a) (1977).

159 A similar approach was taken in Hawaii, which requires that a variance be given only when "[t]he continuation of the function or operation involved in the discharge of waste by the granting of the variance is in the public interest," Hawan REv. STAT. § 3427 (c)(1) (1976), which in turn is to be determined so as to secure the "optimum balance between economic development and environmental quality." Id. § 342-6(c) (Supp. 1980). Other states specify that the competing interests to be considered are those of the applicant, of other property owners likely to be affected by the discharge, and of the general public. E.g., Nev. Rev. Stat. § 445.506(2) (1979); N.M. Stat. ANn. § 74-2-8(B) (1979); Vt. Stat. ANn. tit. 10, § 561(b) (1973); WASH. Rev. Code ANN. § 70.94.181(b)(2) (1975). 
greater benefits"160 suggest that a polluter can obtain a variance whenever he can demonstrate that control costs are marginally greater than the less easily measured harm done by allowing the pollution. But to determine de novo in every case whether compliance is a good thing is to nullify the administrative benefits of adopting general regulations. In contrast, the Illinois statute authorizes variances only when compliance would "impose an arbitrary or unreasonable hardship." 161 The state Pollution Control Board has construed this to mean that "a variance is to be granted only in those extraordinary situations in which the cost of compliance is wholly disproportionate to the benefits; doubts are to be resolved in favor of denial."162 This approach should keep the variance process manageable.

Several states that employ the "equal" public benefits test substitute more demanding terms for "serious hardship." The air pollution control law in Kentucky, for example, allows a variance

[i]f the hearing board finds that because of conditions beyond control compliance... will result in an arbitrary and unreasonable taking of property or in the practical closing and elimination of any lawful business, occupation or activity, in either case without a sufficient corresponding benefit or advantage to the people in the reduction of air contamination. ${ }^{163}$

The use of "unreasonable" suggests that the Kentucky standard is similar to the Illinois position, but closer inspection reveals significant differences. On the one hand, Kentucky allows a variance whenever the cost of closing a business outweighs the benefits, without requiring that the cost be unreasonable; on the other, Kentucky does not allow a variance unless a business is closed or a "taking" of property occurs, even if the costs of compliance are unreasonable when compared with the benefits. ${ }^{184}$ The use of the phrase "because of conditions beyond control" in a number of stat-

100 There also are alternatives, such as those referring to "corresponding benefit," CAL. Health \& SAFETY Code $\$ 42352$ (West 1979), and to "sufficient corresponding benefit or advantage to the people," Ky. REv. Stat. \& 77.260(1) (1971).

361 ILL. REv. STAT. ch. 1111/2, f 1035 (1979).

161 EPA v. Lindgren Foundry Co., 1 III. P.C.B. 11, 16-17 (1970). Minnesota's reference to "undue hardship" in its variance clause, MinN. Stat. ANN. § 116.07(5) (West 1977), is susceptible to the same interpretation.

103 Ky. REv. Stat. \& 77.260(1) (1970).

1er These drawbacks led to the abandonment of a nearly identical formulation in an earlier Illinois air pollution law. See Air Pollution Control Act § 11(a), 1963 Ill. Laws 3198 (repealed 1970). 
utes, such as Kentucky's, seems to import an appropriate requirement of good faith, which has also been found to be implicitly relevant to the interpretation of "unreasonable hardship" in Illinois. ${ }^{105}$ Oregon departs from the standard form by listing the particular hardships that justify a variance:

The commission shall grant such specific variance only if it finds that strict compliance with the rule or standard is inappropriate because:

(a) Conditions exist that are beyond the control of the persons granted such variance; or

(b) Special circumstances render strict compliance unreasonable, burdensome or impractical due to special physical conditions or cause; or

(c) Strict compliance would result in substantial curtailment or closing down of a business, plant or operation; or

(d) No other alternative facility or method of handling is yet available. ${ }^{168}$

There is an obvious danger that some types of real hardships may be inadvertently omitted from such a list, making it impossible for a deserving firm to obtain a variance.

Some states impose other limits on the balancing process. In North Carolina, for instance, variances are authorized only if "[t]he discharge of waste or emission of air contaminants occurring or proposed to occur do [sic] not endanger human health or safety."167 Health and safety are given absolute protection. We do not forbid all driving that endangers human life, however, for the costs would be too great. Similarily, absolute health protection in a pollution statute entails the risk that a significant portion of industry would be closed down. A few states carry absolute protection

${ }^{163}$ See Currie, Enforcement, supra note 1, at 420-26.

168 Or. Rev. Stat. § 468.345 (1979).

187 N.C. GEN. StAT. \& 143-215.3(e)(1) (Supp. 1979). Other statutes with comparable restrictions include HawaII Rev. Stat. § 342-7 (Supp. 1979) (no variance if pollution would "substantially endanger human health or safety"); KAN. STAT. ANN. § 65-3013 (Supp. 1979) (no variance where pollution would "endanger or tend significantly to endanger human health or safety"); NEv. REv. STAr. $\$ 445.506$ (1977) (no variance if "human" health or safety would be endangered); N.M. STAT. ANN. \$ 74-2-8 (1979) (no variance if pollution endangers or tends to endanger "health or safety"); VT. STAT. ANN. tit. 10, 561 (1973) (no variance if "human" health or safety would be endangered); WASH. REv. CoDE ANN. § 70.94.181 (1975) (no variance if "public" health or safety would be endangered). But cf. NEB. REv. STAT. § 81-1513 (1976) (variance may be granted if emissions "do not endanger or tend to endanger human health or safety or . . . compliance . . . would produce serious hardship without equal or greater benefits to the public") (emphasis added). 
even beyond health and safety, making variances nearly impossible to obtain. For example, Alabama forbids variances unless "the emissions occurring, or proposed to occur, do not endanger or tend to endanger human health or safety, human comfort and aesthetic values." "168

Most states provide for variances from the pollution control statutes themselves as well as from the rules and regulations promulgated thereunder. ${ }^{169}$ Iowa, Kansas, Nebraska, Nevada, Ohio, Utah, and Vermont, however, do not allow relief from the statutory provisions. ${ }^{170}$ This omission may be unintentional, as is the case in Illinois. ${ }^{171}$ It probably makes little difference in the case of the Ohio air pollution control program, where almost every prohibition is to be set in motion only at the discretion of the agency. ${ }^{172}$ In a less flexible system ${ }^{173}$ the omission is troublesome.

168 ALA. Codz § 22-28-13(a) (1977). South Carolina, parroting a federal provision since repealed, authorizes its agency to grant variances when it determines that

(1) good faith efforts have been made to comply with such requirement before such date;

(2) such source (or class) is unable to comply with such requirement because the necessary technology or other alternative methods of control are not reasonably available or have not been available for a sufficient period of time;

(3) any available alternative operating procedure and interim control measures have reduced or will reduce the impact of such source on public health;

(4) the continued operation of such source is essential to national security or to the public health or welfare.

S.C. CoDs § 48-1-140(b) (Supp. 1979); accord, 42 U.S.C. § 1857c-5(f)(1) (1976) (repealed 1977), criticized in Currie, Federal Air-Quality Standards and Their Implementation, 1976 AM. BAR Foundation RESEARch J. 365, 380-81. This statute responds poorly to the competing interests. Evidently there can be no variance, however great the hardship, unless the source is "essential." No comparison of the hardship of compliance with the harm of allowing the variance is required or allowed. In addition, the provision permits variances only from enforcement orders; thus in South Carolina variances cannot serve to clarify obligations in advance of prosecution.

109 E.g., Fla. Stat. ANN. \$ 403.201 (West Supp. 1980); Ky. Rev. Stat. $\$ 77.245$ (1970).

${ }^{170}$ Iowa Code AnN. $\S 455 B .22$ (West Supp. 1980); Kan. Stat. ANn. § 65-3013 (Supp. 1979); Neb. Rev. Stat. § 81-1513 (1976); Nev. Rev. Stat. § 445.506 (1979); Ohio Rev. Code Ann. § 3704.03(H) (Page Supp. 1980); Utah Code Ann. § 26-24-11(5) (1976); Vt. Stat. AnN. tit. 10, § 561 (1973).

${ }^{171}$ See ILt. REv. STAT. ch. 1111/2, I 1035 (1979). The unintentional exclusion of the statutory provisions is described in Currie, Enforcement, supra note 1, at 408-09.

${ }_{172}$ See Ohio REv. Cons ANN. $\$ 3704.03$ (Page Supp. 1980) ("director of environmental protection may . . . issue . . . orders prohibiting or abating emissions") (emphasis added).

${ }^{172}$ Iowa is an example. See Iown CoDz ANN. §§ 455B.10-.29 (West Supp. 1980). "The commission shall . . . consider complaints . . . issue orders . . . [and] cause to be instituted by the attorney general . . . legal proceedings to compel compliance . . ." Id. § 455B.12 (emphasis added). 
B. Conditions

The terms of a variance may simply be left to the discretion of the granting agency, as in Pennsylvania, ${ }^{174}$ or they may be dictated by statute. One example is the Florida Air and Water Pollution Control Act, which provides that a "temporary operating permit" granted for traditional variance considerations shall:

1. Specify the manner, nature, volume, and frequency of the discharge permitted;

2. Require the proper operation and maintenance of any interim or temporary pollution abatement facility or system required by the department as a condition of the permit;

3. Require the permit holder to maintain such monitoring equipment and make and file such records and reports as the department deems necessary to insure compliance with the terms of the permit and to evaluate the effects of the discharge upon the receiving waters;

4. Be valid only for the period of time necessary for the permit holder to place into operation the facility, system, or method contemplated in his application as determined by the department; and

5. Contain other requirements and restrictions which the department deems necessary and desirable to protect the quality of the receiving waters and promote the public interest. ${ }^{175}$

Most states have provided some degree of statutory direction as to the terms of a variance between these two extremes. ${ }^{178}$

Even the least structured statutes are almost certain to have a provision requiring a time limitation as a condition of the variance. A number of states limit all variances to one year but make them subject to renewal. ${ }^{177}$ Others set three possible time limitations, each dependent upon the reason for variance. ${ }^{178}$ The New Mexico

174 PA. Stat. ANn. tit. 35, § 4013.5(a) (Purdon 1977).

178 Fra. Stat. AnN. § 403.088(4)(d) (West 1973).

178 See, e.g., Iowa Code AnN. § 455B.22 (West Supp. 1980); OHio Rev. Code ANN. $\S$ 3704.03(H) (Page Supp. 1980).

${ }^{177}$ E.g., Ala. Code $\&$ 22-28-13(c) (1977); Ky. Rev. Stat. \& 77.270 (1970); Mrch. Comp. Laws Ann. § 366.32 (1975); Oho Rev. Code Ann. § 3704.03(H) (Page Supp. 1980); OKLA. Stat. ANN. tit. 63, § 1-1802(J)(d) (West Supp. 1979); R.I. GEN. LAws § 23-25-15(c) (1968); Tenn. Code Ann. $\S 53-3415(C)(8)$ (1977). South Dakota's water pollution law is something of an aberration in that it requires that a variance be "reviewed" every two years. S.D. Codified Laws ANN. § 34A-2-26 (1977).

178 Alaska Stat. § 46.03.170(c) (1977); Kan. Stat. Ann. § 65-3013(c) (Supp. 1979); Neb. Rev. Stat. § 81-1513(3) (1976); Nev. Rev. Stat. § 445.516(1) (1979); N.M. Stat. AnN. § 74- 
statute, for example, provides that:

(1) if the variance is granted on the ground that there is no practicable means known or available for the adequate prevention, abatement or control of the air pollution involved, it shall be only until the necessary means for prevention, abatement or control become known and available;

(2) if the variance is granted on the ground that compliance with the particular requirement or requirements from which the variance is sought will necessitate the taking of measures which, because of their extent or cost, must be spread over a considerable period of time, it shall be for a period not to exceed such reasonable time as, in the view of the board, is requisite for the taking of necessary measures . . . ;

(3) if the variance is granted on the ground that it is justified to relieve or prevent hardship of a kind other than that provided for in Paragraphs (1) or (2) of this subsection, it shall be for not more than one year. ${ }^{179}$

The two exceptions to the one-year limitation appear sensible at first glance. The first, however, is poorly executed, since additional time will be needed to install equipment after it becomes "known and available." Furthermore, while annual renewals may increase administrative costs, they also help to ensure that the agency monitors continuing progress.

Almost all states statutorily allow or require pollution control agencies to attach to variances conditions that serve as alternatives for the regulation being set aside. In Michigan, for example,

[t]he commission shall consider the reasonableness of granting a variance conditioned upon the person effecting a partial control of the particular air pollution or progressive control of the air pollution over a period of time which it considers reasonable under all the circumstances; or the commission may prescribe other and different reasonable regulations with which the person receiving the variance shall comply. ${ }^{180}$

While this power may be implicit in general variance provisions

2-8 (1979); S.D. CoDIPIED LAFs ANN. \$§ 34A-1-31 to -33 (1977) (air pollution variances); VT. Stat. AnN. tit. 10, § 561(c) (1973); Wash. Rev. Code AnN. § 70.94.181(3) (1975); Wyo. Stat. § 35-11-601(b), (c), (e) (1977).

179 N.M. Stat. ANn. § 74-2-8 (1979).

180 Mich. Comp. Laws ANn. § 366.30 (1975). 
that do not specifically grant it, ${ }^{181}$ the inclusion of such a clause increases the probability that a variance will not be a simple license to pollute, but rather a blueprint for compliance as soon as practicable.

The Illinois provision requiring posting of a performance bond, ${ }^{182}$ which I have discussed elsewhere, ${ }^{183}$ is an effort to create a financial incentive toward living up to variance conditions. The effectiveness of such an incentive depends, of course, upon the willingness of the responsible officials to enforce forfeiture.

\section{Variance Procedure}

Many states, though not all, provide for administrative hearings upon variance applications. ${ }^{184}$ The statutory formulas vary. A hearing may be required before a variance can be granted, ${ }^{185}$ or before one can be denied. ${ }^{186}$ Special provisions sometimes require hearings for renewal, revocation, or modification of existing variances. ${ }^{187}$

It seems clear that in general a quasi-judicial hearing is a helpful means of ascertaining the facts relevant to the grant or denial of a variance. Furthermore, if a pollution statute creates a substan-

181 An example is S.D. Codiried Laws ANn. \& 34A-1-30 (1977).

${ }^{182}$ ILL. REv. StaT. ch. 1111/2, I 1036 (1979).

18s Currie, Enforcement, supra note 1, at 471.

184 See, e.g., ArA. CODE $§ 22-28-13(d)$ (1977) (requiring notice of petition in newspaper of general circulation, but allowing grant of variance without hearing unless commission considers hearing advisable, or "any person" files written objection to the variance); ARK. STAT. ANN. \$ 82-1939 (1976) (no hearing required when director recommends grant of variance, except on petition of person aggrieved by such grant); Ky. REv. STAT. $\S 77.250$ (1975) (providing that board "may" hold hearing on own motion or request of any person); N.M. StAT. ANN. § 74-2-8(D) (1979) (requiring a hearing when director recommends granting the variance, and also on request of petitioner when board opposes the variance); OHo REv. Code ANN. § 3704.03(H) (Page Supp. 1980) (providing that director "may" hold hearing); Tenn. Conk ANn. \$ 53-3415(c) (1977) (hearing required only if technical secretary opposed variance, and if board concludes hearing is "advisable"); UTAH CODE ANN. § 26-24-11(5) (1976) (requiring a public "meeting"). Cf. S.D. CodIrIEd LAws ANN. \$§ 34A-1-24 to -27 (1977) (no specific provision for variance hearings).

183 E.g., Alaska Stat. $\$ 46.03 .170$ (1977); VT. Stat. Ann. tit. 10, § 561(b) (1973); Wash. Rev. Code ANn. § 70.94.181(1) (1975).

${ }_{188}$ E.g., Mo. ANN. Stat. \$§ 203.110(4), 204.061(5) (Vernon 1972 \& Supp. 1980); Tenn. Code Ann. § 53-3415(c) (1977); Tex. Rev. Crv. Stat. Ann. art. 4477-5, § 3.22(d) (Vernon 1976) (hearing required only if requested by local government or if pollution control agency concludes it is advisable).

${ }^{187}$ E.g., ARK. STAT. ANN. § 83-1939 (1976) (hearing required before variance can be denied, revoked, or modified); Mrch. Comp. LAws ANN. § 336.33 (1975) (hearing required for revocation, although no hearing required for grant of variance, id. $\S 336.31$ ); OR. REv. STAT. $\S 468.345(5)$ (1979) (hearing required before revocation or modification). 
tive right in the polluter to obtain relief upon meeting prescribed criteria, contemporary Supreme Court opinions strongly suggest that the polluter has a property interest within the protection of the due process clause, and that he is entitled to a quasi-judicial hearing if his allegations state a claim on which relief can be granted. ${ }^{188}$ Although the grant of a variance may adversely affect the polluter's neighbors, it seems unlikely that they are given any comparable property interest by a pollution control statute. ${ }^{189}$ Whether they can require a hearing therefore seems to be up to the state legislature or its delegate, the control agency.

As a policy matter, a hearing seems desirable whenever there is any substantial room for doubt over the facts, even if no one has requested it. This conclusion follows from the frequent absence of any genuine adversary to the variance applicant: neighbors who will be harmed by the grant of a variance often do not make an appearance to contest it. The first obstacle is to notify them. They may be too numerous to make personal notice practicable-an entire city may be affected-and a legal notice in the back pages of a newspaper is likely to go largely unread. Illinois has tried to mitigate the problem by giving personal notice to those who have requested notice of variance applications in their vicinity, ${ }^{180}$ but even this practice is certain to leave many who would be injured by the requested variance uninformed.

Moreover, notice is only the first difficulty. Often those who know of and would be individually harmed by the grant of a variance application will not find it worth the effort to mount a case in opposition, even if the aggregate effect of the variance would be considerable. One common response to this problem is to give a government agency the responsibility to investigate the facts and to present a recommendation to those empowered to pass on the variance. ${ }^{191}$ Illinois experience ${ }^{182}$ suggests this is a useful expedient but not the equivalent of a true adversary process. Among other

18 See Currie, The Mobile-Source Provisions of the Clean Air Act, 46 U. CHr. L. Rav. 811, 844-45 (1979). Like the applicant for bar admission, see Willner v. Committee on Character \& Fitness, 373 U.S. 96 (1963), and the welfare recipient, see Goldberg v. Kelly, 397 U.S. 254 (1970), the polluter claims an "entitlement" that would seem to constitute a property interest protected by the due process clause.

100 See League of Women Voters v. North Shore Sanitary Dist., 1 IIl. P.C.B. 576 (1971).

${ }^{100}$ ILL. Rev. Stat. ch 1111/2, T 1037 (1979).

101 See, e.g., ALA. Cods § 22-28-13(d) (1977); ARK. Stat. ANN. § 82-1939 (1976); ILL. Rev. Stat. ch. 1111/2, T 1037 (1979); N.M. Stat. Ann. § 74-2-8(D) (1979); Trnn. Code Ann. § 53-3415(i) (1977).

192 See Currie, Enforcement, supra note 1, at 468-75. 
things, the recommending agency properly feels that its responsibility is to advocate the outcome best for society as a whole; the arguments of the victims of the variance, therefore, may never be presented to those making the decision. A requirement that an applicant for a variance prove that the cost of compliance significantly outweighs the benefits would be an additional safeguard for the interests of absent victims.

\section{ENFORCEMENT}

\section{A. Cease-and-Desist Orders}

The basic mechanism for enforcement of the pollution laws is the administrative order to cease and desist from violations of the statute or regulations. Cease-and-desist authority apparently exists in every air or water pollution program. ${ }^{193}$ The advantages of administrative rather than judicial enforcement include the value of experience with complex technical issues, the possibility of more expeditious proceedings, the elimination of disparity in interpretation, the avoidance of congestion in the regular courts, and, not least, the possibility of appointing personnel sympathetic to the goals of the program. ${ }^{194}$

As one would expect, a hearing normally precedes issuance of a cease-and-desist order, and it generally resembles a judicial trial. ${ }^{105}$ Most states authorize issuance of orders without a prior hearing in an emergency. ${ }^{106}$ Most, but not all, of these require a hearing within a specified time after issuance of an emergency or-

19s See, e.g., Conn. Gen. Stat. Ann. § 22a-7 (1975); Hawan Rev. STat. § 342-8 (1976). In the District of Columbia the pollution control agency is not explicitly given the authority to issue cease-and-desist orders. It is, however, authorized to "issue such orders as may be necessary to enforce the regulations . . . and enforce such orders by all appropriate administrative and judicial proceedings, including injunctive relief." D.C. CoDE ENCYCL. § 6813(b)(2) (West Supp. 1970). This language appears to include cease-and-desist orders.

${ }^{194}$ Cf. Currie \& Goodman, Judicial Review of Federal Administrative Action: Quest for the Optimum Forum, 75 Corum. L. REv. 1, 62-74 (1975) (discussing the advantages and disadvantages of specialized courts for review of administrative action).

${ }^{105}$ See, e.g., ILr. REv. STAT. ch. 1111/2, ชก 1031-1033 (1979) (providing for pleadings, representation by counsel, cross-examination, stenographic transcription, and written opinions); Mrch. Comp. Laws ANN. $\$ 336.20$ (West 1975) (providing for pleadings, counsel, compulsory process, testimony under oath, and recording of testimony).

106 E.g., Colo. Rev. Stat. §§ 25-7-112 to -113 (Supp. 1979); Iowa Code ANN. § 455B.18 (West Supp. 1980); Kan. Stat. Anv. § 65-3012 (Supp. 1979); N.H. Rev. Stat. Ann. § 125:84 (1978); N.Y. Envir. Conserv. Law $\$ 71-0301$ (McKinney Supp. 1979); Ohio Rev. Code ANn. § 3704.032 (Page 1980); Utah Code Ann. § 26-24-11(4) (1976). 
der; ${ }^{197}$ due process probably requires that a hearing take place as soon as practicable. ${ }^{198} \mathrm{~A}$ number of states provide an additional safeguard against abuse of the emergency power by requiring that such orders be issued or approved by the Governor. ${ }^{189}$

To obtain sanctions for the violation of an administrative order, it is necessary in most states to go to court. ${ }^{200}$ This two-step process can delay enforcement and weaken the agency, especially in the extreme case in which a court may examine the order de novo. ${ }^{201}$ Often, however, judicial review is limited to whether the agency acted arbitrarily, unreasonably, or contrary to the manifest weight of the evidence. ${ }^{202}$ This traditional standard of appellate re-

107 Colorado, New Hampshire, and Ohio, for example, make no mention either of time or of a hearing. Colo. Rev. Stat. \$\$ 25-7-112 to -113 (Supp. 1979); N.H. Rev. Stat. ANN. § 125:84 (1978); OHIo REv. CoDE ANN. § 3704.032 (Page 1980). A number of states require hearings within 24 hours. E.g., Kan. Stat. ANN. § 65-3012 (Supp. 1979); Utar Cods ANn. $\S 26-24-11(4)$ (1976); VT. STAT. ANN. tit. 10, § 560 (1973). In contrast, Nebraska allows 10 days before the hearing, NeB. Rev. Stat. \$ 81-1507(4) (1976), and New York allows 15, N.Y. Envir. Conserv. Law \& 71-0301 (McKinney Supp. 1979).

${ }^{10 s}$ See, e.g., Commissioner v. Shapiro, 424 U.S. 614, 629 \& n.11 (1976) (construing statute narrowly to avoid constitutional problem caused by lack of hearing); North Ga. Finishing, Inc. v. Di-Chem, Inc., 419 U.S. 601 (1975).

109 E.g., Kan. Stat. AnN. § 65-3012 (Supp. 1979); N.H. Rev. Stat. Ann. § 125:84 (1978); Ohio Rev. Code Ann. $\$ 3704.032$ (Page 1980); Vt. Stat. Ann. tit. 10, $\$ 560$ (1973). Utah requires not only the Governor's concurrence, but also that a hearing be held before the Governor within 24 hours after the emergency order is issued. UTAH CODE ANN. § 26-2411(4) (1976). South Carolina merely requires notice to the Governor, who can then order that a hearing be held within 48 hours after the emergency order is issued. S.C. ConE $\$ 48-1-$ 290 (1977).

${ }^{100}$ E.g., Alaska Stat. $\$ \S 46.03 .760, .765$ (1977); ARIz. Rev. Stat. AnN. $§ \S 36-787,-1715$ (1974); id. §§ 36-1864, -1864.01 (Supp. 1979); ARK. StAT. ANN. § 82-1909 (1976); Colo. Rev. Stat. §§ 25-7-2, -122 (Supp. 1979); Conn. Grn. Stat. ANn. § 19-516 (West 1977); DeL. Code ANN. tit. 7, § 6005 (Supp. 1978).

201 E.g., ARK. STAT. ANN. $\$ 82-1906(7)$ (1976) (court may in its discretion and on own motion or motion of party take additional evidence on any issue or try any or all issues de novo; no jury); IND. STat. ANN. § 13-1-3-11 (Burns 1973) (action for compliance "shall" be tried de novo, with right to jury); N.C. GEN. STaT. § 143-215.5(b) (1978) (matter "shall be heard and determined de novo on the transcript [of the administrative hearing] . . . and any . . . additional evidence"); W. VA. CODE $\S 16-20-10$ (1979) (emergency orders reviewed de novo).

${ }^{203}$ E.g., ARIz. Rev. StaT. ANv. § 36-1868(c) (Supp. 1979) (review in trial court limited to "whether administrative record as may be supplemented by other evidence supports such order or determination by substantial evidence"); TeNN. CoDE ANN. $₹$ 70-333 (Supp. 1979) (review on transcripts only, and only as to whether decision was supported by substantial evidence); UTAH CODE ANN. \$ 26-24-12 (1976) (review in state supreme court on transcripts, limited to whether agency acted without or in excess of powers and whether findings were supported by substantial evidence); VA. CoDs $\$ 10-17.23: 2$ (Supp. 1978) (air pollution) (review on transcript, order, exhibits, and "such additional evidence as may be necessary to resolve any controversy as to the correctness of the record" or "as the ends of justice require"; no jury; court may modify or reverse if board acted unconstitutionally, in excess of 
view leaves debatable technical questions and policy matters to the expert administrative body while preserving some vestige of the constitutional assignment of judicial power to the courts. ${ }^{203}$

\section{B. Civil and Criminal Penalties}

If no penalties could be assessed until after an administrative cease-and-desist order had been violated, the polluter would get one free bite; there would be no incentive for a polluter to comply until caught. Consequently, most states authorize the imposition of penalties for violations of the law and regulations as well as of an earlier cease-and-desist order. Some allow the agency itself to impose monetary penalties; ${ }^{204}$ in others, the agency, or the state attorney general on its behalf, must go to court. ${ }^{205}$

The nominal amounts of permissible penalties are in many cases rather trivial. Nevada, for example, limits the penalty for a violation to not more than $\$ 5,000 .^{206}$ Yet "each day of violation" under the Nevada statute "constitutes a separate offense", ${ }^{207}$ even a small sum, compounded daily, may mount up significantly over time. Nevertheless, such limits may make the threat of a penalty an insufficient incentive for compliance when the cost of control equipment is in the millions of dollars. Connecticut's basic approach is preferable. While absolute numerical limits unfortunately remain, Connecticut authorizes its commissioner to establish a penalty schedule in such amounts "as to insure immediate and continued compliance with applicable laws, regulations, orders and permits." 208 Violation, in other words, is to be made more expensive than compliance. ${ }^{209}$

authority or jurisdiction, on unlawful procedure or other error of law, or if action was "unsupported by the evidence on the record considered as a whole" or was "arbitrary, capricious, or an abuse of discretion"); id. § 62.1-44.29 (1973) (water pollution) (same).

${ }^{20 s}$ See generally $4 \mathrm{~K}$. Davis, Administrative Law Treatise $\$ \$ 29.01-11$ (1958).

${ }^{204}$ E.g., Conn. Grn. Stat. Ann. § 22a-6b (West 1975 \& Supp. 1980); InL. Rev. Stat. ch. 1111/2, I 1033(b) (1979); Nev. REv. STAT. § 445.601 (1979).

${ }^{203}$ E.g., AlA. CoDe $\S 22-28-22$ (1975); Iowa CODE ANN. § 455B.25 (West Supp. 1980); N.M. Stat. AnN. § 74-2-12 (1979); N.D. Cent. Code $\S \S 23-25-10$ (1978); id. § 61-28-08 (Supp. 1979).

${ }_{206}$ Nev. Rev. Stat. $\$ 445.601$ (1) (1979).

207 Id.

108 Conn. Gen. Stat. Ann. § 22a-6b(a) (West Supp. 1980).

${ }^{209}$ Similar statutes include AlAsKa STAT. $\$ 46.03 .760$ (1977) ( $\$ 500$ to $\$ 100,000$ for initial violation and up to $\$ 5,000$ per day thereafter, "which shall reflect . . . the economic savings realized by the person in not complying with the requirement for which a violation is charged," $i d$. $\$ 46.03 .760(\mathrm{a})(3)$; the penalty must not, however, be punitive-only "compensatory and remedial," id. § 46.03.760(b)); Kan. STaT. ANN. § 65-170d (Supp. 1979) (penalty 
Criminal sanctions also are commonly provided, but usually only for intentional or, in some cases, "criminally negligent" violations. ${ }^{210}$ No criminal penalties are provided for water pollution infractions in at least one state, Georgia. ${ }^{211}$

\section{Expenses and Damages}

In addition to penalties, an agency frequently has the power to seek compensation from a polluter. For instance, Nevada provides that actual damages to the state may be recovered, ${ }^{\mathbf{2 1 2}}$ including "any expenses incurred in removing, correcting and terminating any adverse effects resulting from the discharge of pollutants" and "compensation for any loss or destruction of wildlife, fish or aquatic life and any other actual damages caused by the violation."213

\section{Permits}

Permit requirements for potential pollution sources serve a number of purposes. Permit systems facilitate the collection of necessary information; ensure continual surveillance rather than spasmodic responses to complaints; make it possible to prevent rather than merely abate pollution; allow a polluter to obtain a determination that proposed control devices will suffice before making an actual investment in them; and make enforcement easier by requiring the polluter to prove compliance with the law. ${ }^{214}$

For these reasons, and in order to qualify for participation in

of up to $\$ 10,000$ per violation per day in an amount that "shall constitute an actual and substantial economic deterrent to the violation," id. § 65-170d(b)); Wrs. STAT. ANN. $\$ 147.21$ (West 1974) ("In determining the amount of the fine . . . the court shall assess an amount which represents an actual and substantial economic deterrent to the action which was the basis of the conviction," $i d$. \$ 147.21(3), up to varying maxima dependent upon whether the pollution was a first offense or was intentional).

210 E.g., IND. CoDr ANN. \& 13-7-13-3 (Burns Supp. 1980) ("intentionally, knowingly, recklessly, or negligently"); Nzv. REv. STAT. § 445.334 (1979) (criminal penalties for anyone "who intentionally or with criminal negligence" commits violation). Cf. ARIz. Rzv. Stat. ANN. § 36-1864.02 (Supp. 1979) (most violations of statute or regulations are punishable as a class 2 misdemeanor; "criminal negligence" makes the discharge of a pollutant a class 1 misdemeanor).

${ }^{211}$ See GA. Cods ANN. §§ 17-502 to -528 (Supp. 1980). Id. § 17-521.2 provides for civil penalties only.

212 Nev. Rev. Stat. § 445.331(2) (1979).

${ }^{213} I d$. $\S 445.331$ (3). The most complex monetary provisions are found in relation to oil spills, e.g., VA. CoDs § 62.1-44.34 (Supp. 1980).

214 See Currie, Enforcement, supra note 1, at 476. 
federal pollution control programs, ${ }^{215}$ nearly every state pollution statute requires permits for the construction or operation of potential sources, or for both. ${ }^{216}$ In a few states it is left to the discretion of the agency whether to require permits ${ }^{217}$ or to delineate the classes of pollution sources for which permits are necessary. ${ }^{218}$ Some statutes contain sensible exceptions for trivial sources, ${ }^{219}$ or delegations of the authority to make such exceptions. ${ }^{220}$ Construction permits are more commonly required by air pollution statutes than operating permits. ${ }^{221}$ States that make no provision for the latter are forgoing an important enforcement device and information source with respect to existing installations.

Until 1977 a state could participate in the federal air pollution program without requiring any permits at all, so long as it provided for preconstruction "review" of the "location" of any new source. ${ }^{222}$ While a permit program was the obvious means of providing such review, it was not the only means. The statute made it

11s See 33 U.S.C. § 1256(f)(2) (1976); id. §§ 1319, 1342 (Supp. II 1978); 42 U.S.C. $\S \S 7405,7410(\mathrm{a})(2)(\mathrm{D})$ (Supp. II 1978).

${ }^{216}$ A number of states specifically enclose the NPDES program in their pollution control statutes. E.g., ARK. STAT. ANN. § 82-1904 (12)(2) (1976); GA. Code ANn. § 17-505(a)(16) (Supp. 1980); Minn. Stat. AnN. § 115.03 (5) (West 1977); NeB. Rev. Stat. § 81-1505(11), (19) (Supp. 1979); id. § 81-1506(2)(a) (Supp. 1978); Nev. REv. STAT. § 445.214 (1979); N.Y. EnviR. Conskrv. Law \$§ 17-0801 to -0829 (McKinney Supp. 1979); Tenn. Code Ann. \$ 70328(8) (Supp. 1979); VT. Stat. ANN. tit. 10, § 1258(b) (Supp. 1980); Wash. Rev. Code ANn. § 90.48.260 (Supp. 1980); W. VA. CoDE \& 20-5A-3(a)(1) (Supp. 1980). In other states, different combinations of the following activities may be carried out only under permit: installation, construction, modification, alteration, operation, use or maintenance of pollution sources or control devices, or discharge therefrom. See, e.g., Ill. Rev. Stat. ch. 1111/2, I 1039(a) (1979).

317 E.g., Cal. Health \& Safety Code $\$ 42300$ (West 1979); Conn. Gen. Stat. Ann. $\S 22 a-6(4)$ (West 1975); Kan. Stat. ANN. § 65-3008 (Supp. 1979); N.M. STAT. ANN. § 74-2-7 (1979).

218 E.g., Mo. ANN. StaT. § 203.075(1) (Vernon Supp. 1980) (unlawful to commence construction of a contaminant source without permit "if such source is of a class fixed by regulation of the commission which requires a permit therefore"); W. VA. CoDE § 16-20-11b (1972) ("commission shall by rule and regulation specify the class or categories of stationary sources" for which permits will be required).

210 E.g., ARK. Stat. ANN. \$ 82-1934 (1976) (exempting, inter alia, noncommercial barbecue equipment); Cal. Health \& SAFETY Code § 42310 (West 1979) (same).

${ }^{220}$ E.g., Colo. Rev. Stat. § 25-7-114(5)(a) (Supp. 1979); Wash. Rev. Codz AnN. $\S 90.48 .160$ (Supp. 1979).

${ }^{221}$ Compare Alaska STAT. $\$ 46.03 .160$ (1977) ("construction, installation or establishment"); CoLo. Rev. Stat. § 25-7-112 (1974) (construction, substantial alteration, installation, and "commencement" of operation, conduct or performance) and N.M. STat. ANN. § 74-2-7 (1979) ("constructing or modifying") with NEv. REv. STAT. § 445.491 (1979) ("operating permits").

${ }_{223}^{282}$ U.S.C. $\S 1857 \mathrm{c}-5(\mathrm{a})(2)(\mathrm{D})(1976)$ (revised and transferred to 42 U.S.C. $\$ 7410$ (Supp. II 1978) by Act of Aug. 7, 1977, Pub. L. No. 95-95, 91 Stat. 691). 
clear that a state satisfied the federal requirements if it provided "adequate authority to prevent the construction or modification of any new source ... at any location which ... will prevent the attainment and maintenance . . . of a national ambient air quality .. . standard," and required that the owner "submit . . . such information as may be necessary to permit the State to make a determination" under the former clause. ${ }^{223}$ Among the few jurisdictions that have no permit provisions, Vermont and Wisconsin appear to require the information and confer the authority formerly requisite for participation in the federal program; ${ }^{224}$ the District of Columbia and Oklahoma do not. ${ }^{225}$ Amendments to the federal law in 1977 provide that a state pollution control plan will not qualify unless it requires permits for all major new sources, ${ }^{228}$ and it seems likely that the carrot of federal grants ${ }^{227}$ will bring about the enactment of additional state permit requirements in the near future..$^{228}$

The basic criterion for issuance of a permit follows logically from its purposes: a permit will be granted upon a showing that the activity will conform to all applicable substantive requirements. ${ }^{229}$ Various conditions are often imposed on the permit re-

${ }_{223} 42$ U.S.C. $\S 1857 \mathrm{c}-5(\mathrm{a})(4)$ (1976) (revised and transferred to 42 U.S.C. $\$ 7410$ (Supp. II 1978) by Act of Aug. 7, 1977, Pub. L. No. 95-95, 91 Stat. 691).

226 VT. Stat. ANN. tit. 10, $\S 554(4)$ (authority to issue "orders as may be necessary to effectuate the purposes of this chapter"); $i d$. $\$ 555(b)$ (1973) (required reports from operators of air contaminant sources); id. $\S 559$ (authority to order "prevention" of emissions); Wis. Stat. ANN. 144.31 (West 1974) (authority to issue "orders to effectuate the purpose" of the chapter); id. § 144.35(1)(b) (authority to issue "appropriate order for the prevention . . . of the problems involved" in a violation); id. $\S 144.38$ (required reports from operators of those types of air contaminant sources specified by state pollution control agency).

${ }_{228}$ D.C. Conz Encycl. $\$ \S 6-811$ to -813 (West Supp. 1970); OкLA. STat. ANn. tit. 63, $\S \S 1-1801$ to -1808 (West Supp. 1979).

226 42 U.S.C. $\$ \S 7410(a)(2)(D), 7475,7502(b)(6)$ (Supp. II 1978).

${ }_{227}$ Id. $\S 7405$ (Supp. II 1978).

228 Indeed, New York and Louisiana, which formerly had no provision for air pollution permits, enacted permit provisions in 1979. N.Y. ENvIR. Conserv. LAw $\$ \S 19-0301$ to -0302 (McKinney Supp. 1979); LA. Rev. Stat. ANN. §§ 30:1084-:1085 (Supp. 1980).

220 See, e.g., Cat. Health \& SAFETY Code $\S 42301$ (Wegt 1979) (requiring that the "article, machine, equipment or contrivance for which the permit was issued shall not prevent or interfere with the attainment or maintenance of any applicable air quality standard," id. \& 42301(a), and "will comply with all applicable orders, rules, and regulations," id. § 42301(b)); CoLo. Rev. Stat. \& 25-7-114(g)I(A) (Supp. 1978) ("proposed source or activity" must "meet all applicable emission control regulations"); FlA. STAT. ANN. $\$ 403.087$ (West Supp. 1980) (permit allowed "only when . . . the installation is provided or equipped with pollution control facilities that will abate or prevent pollution to the degree that will comply with the standards or rules promulgated by the department ... and which will comply with [federal regulations]"). 
cipient to assure compliance, ${ }^{230}$ permits are usually issued for a limited but renewable period, in order to assure reconsideration; ${ }^{231}$ and revocation of the permit is generally provided as a remedy for violation of permit conditions. ${ }^{232}$

As in the case of variances, ${ }^{293}$ many states attempt to provide an opportunity for the general public to participate in the permit process. Colorado requires that notice of permit applications be "circulated in a manner to inform interested and potentially interested persons of the proposed discharge and of the proposed determination to issue or deny a permit,"234 but it gives little guidance on the vexing question of how that is to be accomplished.285 Texas requires notice to "persons who in the judgment of the commission may be affected"236 - an impossible task if individual notice is contemplated in all cases, and as unhelpful a formulation as Colorado's if it is not. ${ }^{237}$ Other approaches to the same problem have

\footnotetext{
2so E.g., Mo. ANN. Stat. § 204.051(3) (Vernon Supp. 1980) (if source "meets or will meet" requirements of law and regulations, agency secretary "shall issue a permit with such conditions as he deems necessary to insure that the source will meet the requirements [of the act] and any federal water pollution control act as it applies to sources in this state"); N.M. Stat. AnN. § 74-2-7(G) (1979) (permit may be conditioned on "individual emission limits," "a requirement that such source install and operate best available control technology . . . or technology sufficient to achieve the lowest achievable emission rate . . . to the extent necessary to meet the requirements of the federal act" and "reasonable restrictions and limitations other than restrictions and limitations relating to emission limits or emission rates"); OHro REv. CODE ANN. § 3704.03(G) (Page 1980) (permits conditioned on right of entry in reasonable fashion for inspection purposes).

${ }^{2 s 1}$ E.g., Nev. Rev. Stat. $\$ 445.227$ (1979) (water pollution permits issuable for "fixed terms not to exceed 5 years").

${ }^{238}$ E.g., CaL. Health \& Sarety Code $§ 42307$ (West 1979) (revocation may be sought if air pollution permit holder is in violation of "any applicable order, rule, or regulation"); CoLo. Rev. Stat. § 25-8-604 (1974) (suspension, modification or revocation for violation of permit provision); FLA. STAT. ANN. § 403.087(6) (West 1973) (revocation for false or inaccurate information in application; violation of law, orders, rules, regulations, or permit conditions; failure to submit operational reports or refusal to permit inspection). Cf. Mo. STAT. ANN. § 204.056(4) (Vernon Supp. 1980):

[Permits] may be terminated or modified if obtained in violation [of the act] or by misrepresentation or failing to fully disclose all relevant facts, or when required to prevent violations of any provision [of the act] or to protect the waters of this state, when such action is required by a change in conditions or the existence of a condition which requires either a temporary or permanent reduction or elimination of the authorized discharge .... .

23s See text at notes 184-192 supra.

234 Colo. Rev. Stat. \& 25-8-502(3) (1974).

22s The statute calls only for "circulation" in the geographic area of the discharge and mailed notice to those who ask to be on a mailing list to be maintained by the pollution control agency. Id. $\$ 25-8-503$.

2s6 Tex. Water Code ANn. tit. 2, § 26.028 (Vernon Supp. 1980).

2s7 The statute does call for notice of certain permits to be given to the mayor and local
} 
been discussed above in connection with variances. ${ }^{238}$

Many state air or water pollution programs provide for some type of public hearings on permit applications. Under the Connecticut water statute, hearings are mandatory in all cases; ${ }^{239}$ such a requirement may impose an unnecessary burden when the facts are not subject to dispute. ${ }^{240}$ More commonly, hearings are mandatory only on denial of a permit, and then only when requested by the aggrieved applicant, ${ }^{241}$ presumably because only the applicant is likely to have a constitutionally protected interest in the matter. ${ }^{242}$

\section{Institutional ARrangements}

Illinois has a unique mechanism for the administration of its pollution control program. An Environmental Protection Agency subject to the Governor fills the role of prosecutor; an independent Pollution Control Board, composed of full-time officials, acts as the rulemaking and adjudicatory authority; and long-range planning is in the hands of an independent Institute of Natural Resources. ${ }^{248}$ As I have pointed out previously, ${ }^{244}$ I believe this is a highly desirable enforcement system.

Unfortunately, no other state has followed this example. Instead, three basic organizations have been employed: (1) the executive department, or a division thereof; (2) a part-time board of citizens, executive department representatives, and/or interest representatives, employing an executive secretary and staff; and (3) an executive department in conjunction with a part-time board or

health officials. In addition, an applicant may choose to attempt to avoid a hearing by publishing notice in newspapers and submitting a list of people he expects will be affected to the state agency; if neither a member of the public nor an official of the state agency complains, no hearing is necessary. Id.

2so See text at notes 184-192 supra.

238 Conn. Gen. Stat. Ann. $§ 25-54$ (West Supp. 1980). Cf. VT. Stat. Ann. tit. 10, $\S 1263$ (b) (1973) (requiring agency to give notice and "opportunity" for hearing or written comments before deciding).

340 This stringent requirement is particularly surprising in light of the state's air statute, which makes no provision for holding hearings in relation to permits for the construction or modification of a pollution source, see CoNN. GEN. STAT. ANN. § 19-519a (West 1977), and even as to variances, requires hearings only before an application may be granted, $i d$. $\S 19-519$. In either case, for an applicant who has been denied a permit, the only statutory means of relief is to appeal to the courts. Id. $\$ 19-918$ (West Supp. 1980).

${ }^{341}$ E.g., Alaska Stat. \$ 46.03.160(c) (1977); INd. Code ANn. § 13-7-10-4 (Burns Supp. 1980); Mont. Rev. Codes Ann. § 75-5-403 (1979); N.M. Stat. Ann. § 74-2-7(K), (L) (1979).

313 See text and notes at notes 188-189 supra.

213 ILl. Rev. StaT. ch. 1111/2, ff 1004-1006.1 (1979).

24 See Currie, Enforcement, supra note 1, at 444-49. 
commission.

\section{A. The Executive Department}

Many states have chosen to place one or more of their pollution control programs under the sole administration of an executive department. ${ }^{245}$ Alaska, for example, has a separate executive department, headed by a commissioner of environmental conservation, that administers a coordinated program for controlling pollution of water, land, air, and other resources. ${ }^{246}$ The powers of the Alaska department are comprehensive. It has "responsibility for coordination and development of policies, programs and planning," and for both "promulgation and enforcement of regulations setting standards for the prevention ... of pollution."247 Although one avenue of enforcement is to seek injunctions or civil or criminal penalties in the courts, ${ }^{248}$ the statute also authorizes the department itself to issue "compliance orders" to violators. ${ }^{249}$ Thus the department combines the executive function of prosecution, the legislative function of rulemaking, and the judicial function of adjudication.

The great advantages of such a unified structure are professionalism and efficiency. No responsibility is given to part-time amateurs; there are no multiple staffs duplicating each other's work. The great disadvantage is the loss of the important protections against abuse of authority found in the typical constitutional separation of powers. The most disturbing consequence is that under such statutes the same agency that prosecutes a charge determines whether it has proved its own case.

Thus in Alaska a person to whom a notice of violation and a subsequent compliance order has been issued by the "department" is entitled to a hearing before the same body; after the hearing, it

245 See, e.g., Conn. Gen. Stat. AnN. $\$ \$ 19-505$ to -520a (West 1977 \& Supp. 1980); id. $\S \S 22 a-2$ to $-10,25-54 a$ to $-54 \times x$ (West 1975 \& Supp. 1980) (air and water pollution control programs administered by commissioner of environmental protection. It should be noted that Connecticut does provide for the creation of an independent board, but its duties are purely advisory and it has no real control over the state's pollution control efforts. See id. $\S \S 22 a-11$ to -13 (West 1975 \& Supp. 1980).); Ohio Rev. Codz. ANN. \$§ 3704.01-.09 (Page 1980); id. \$§ 6111.01-.99 (Page 1977 \& Supp. 1980) (air and water programs under a director of environmental protection).

${ }^{248}$ See generally ALasKa STat. $\$ \S 44.46 .010-020$ (1976); id. $\S \S 46.03 .010-.35 .210$ (1977 \& Supp. 1979).

s'7 Id. § 44.46.020(1)-(2) (1976).

${ }^{318}$ Id. $\S \S 46.03 .760, .765, .790$ (1977).

219 Id. $\S 46.03 .850$. 
is the same "department" that determines whether or not to rescind the initial order. ${ }^{250}$ Under the Alaska Administrative Procedure Act" the hearing is conducted by a "qualified, unbiased, and impartial hearing officer," ${ }^{252}$ but this requirement falls considerably short of a meaningful separation of prosecutorial and judicial functions. The hearing officer himself, despite the comforting terms "unbiased" and "impartial," is assigned by the Governor,"25s who is also ultimately responsible for prosecution. The hearing officer "may perform other duties," apparently even within the agency, ${ }^{254}$ and there is no prohibition on his working with the prosecutorial staff. The agency itself may hear the case "with the hearing officer," and if it does it may retain all authority over the hearing except to "rule on the admission and exclusion of evidence."255 While the hearing officer is required to prepare a "proposed decision" if he hears the case alone, and to be present at any deliberations concerning a case he heard with the agency, the department need not give his findings any deference whatever in making the ultimate decision. ${ }^{288}$ Thus the commissioner is prosecutor and judge in the same case. If this is not considered a deprivation of property without due process, ${ }^{257}$ it should be; and it ought to be changed as a matter of policy.

The Alaska statute also calls for an environmental advisory board. ${ }^{258}$ These advisory boards commonly are created by states in which the administration of the control program is vested solely in an executive department, ${ }^{259}$ although they are also present in other types of administration. ${ }^{260}$ The Alaska board consists of the commissioner of environmental conservation, serving as chairman, and eight members, not officers or employees of any state agency, serv-

$250 I d$.

ss1 Id. \$ 44.62.010-.650 (1976 \& Supp. 1979), made applicable by $i d$. $\$ 46.03 .880$ (1977).

152 Id. $\S 44.62 .350$ (1976).

253 Id.

$234 I d$.

153 Id. $\S 44.62 .450$.

256 Id. $\$ 44.62 .500$.

${ }^{287}$ Compare In re Murchison, 349 U.S. 133 (1955) (combination of judicial and grand jury functions constituted violation of due process) and In re Schlesinger, $404 \mathrm{~Pa} .584,172$ A.2d 835 (1961) (disbarment hearings where court's Committee on Offenses acted as prosecutor, judge, and jury constituted violation of due process) with Withrow v. Larkin, 421 U.S. 35 (1975) (combining investigative and adjudicative functions in licensing body did not constitute violation of due process) (semble).

158 Alaska STat. $\$ \$ 44.46 .030-.050$ (1976).

2s9 See, e.g., the Connecticut statutes discussed in note 245 supra.

${ }^{200}$ See, e.g., VA. Code $\$ \S 10-17.9: 1-.30: 1$ (1978 \& Supp. 1980). 
ing at the pleasure of the Governor. ${ }^{261}$ They receive a modest per diem allowance and expenses. ${ }^{262}$ The board's duties are to "advise the commissioner," "serve as a forum" for debate on the environment, recommend outstanding environmentalists for recognition by the state, and "perform such other functions as may be requested by the commissioner."26s Although this board could be made a significant source of valuable advice if the department so chose, it seems more likely that its principal function will be maintaining good public relations.

\section{B. Nonadvisory Board with Executive Secretary}

Virginia vests all powers of air pollution control in a five-member Air Pollution Control Board, ${ }^{264}$ whose members are to be selected "for their ability," "without regard to political affiliation," and who may not be "officer[s] or representative[s] of any industry, county, city or town which may become subject to the rules and regulations of the Board."26s Members receive "fifty dollars per day, plus reasonable and necessary expenses, for each day or portion thereof in which the member is engaged in the business" of the Board. ${ }^{268}$ They are required to meet "at least every three months."287

This Board is given the authority to adopt regulations, to grant variances, to investigate violations, to "initiate and receive complaints," to "enter orders for the purpose of enforcement of its rules or regulations," and to institute court enforcement proceedings. ${ }^{268}$ It is also authorized to hire a staff and appoint a full-time "executive director," who "shall exercise such authority to administer and enforce the provisions of this chapter and rules, regulations and orders of the Board as is conferred upon him by the

se1 ALASKA Stat. $\$ 44.46 .030$ (1976). The members are appointed to staggered terms. Id.

s62 Id. § 44.46.040.

${ }^{20 s}$ Id. \$ 44.46.050.

zes VA. CoDe $\S \S 10-17.9: 1-.30: 1$ (1978 \& Supp. 1980).

2es Id. § 10-17.12 (Supp. 1980).

${ }^{268}$ Id. $\$ \S 2.1-20.3-.4$ (Supp. 1980). Board members are appointed for staggered fouryear terms by the Governor and must be confirmed by the legislature. Id. $\$ 10-17.11$ (1978). It is worth noting the contrast with the Alaska appointment process, see text and note at note 261 supra. The Virginia Board's greater powers apparently led the legislature to retain more control over and leave the Governor less discretion in the appointment of board members.

${ }^{267}$ VA. CoDE \& 10-17.15 (1978).

${ }^{208}$ Id. $\S 10-17.18$ (Supp. 1980). 


\section{Board."268}

The appointment of a citizen board appears to be an effort to broaden the base of decision making and to avoid the dangers of bureaucratic stagnation. But pollution control is not a task that can be performed intelligently by essentially unpaid amateurs meeting four times a year. The Virginia scheme seems to ensure that those charged with the ultimate administrative authority over pollution control will not have the foggiest notion of what they are doing.

Moreover, this structure fails to provide a meaningful separation of prosecutor and judge. Nothing in the statute ensures that the Director is to prosecute and the Board is to decide. The statute allows the Board to delegate to him both functions or neither. Presumably the Board might itself create an ostensible separation of functions by delegating the entire prosecution task while retaining the power of decision, but in the absence of sufficient expertise and paid time to reach an independent decision, it seems all too likely that the Board would still be essentially the puppet of the Director.

Some statutes of this type limit the functions that may officially be delegated to the Director. Virginia's Water Pollution Control Board, for example, must itself promulgate regulations, revoke certificates and permits, and issue enforcement orders. ${ }^{270}$ This variation does little to overcome the objections rehearsed above. In the first place the statute does not require the Board to divest itself of authority over the institution and control of prosecution. Moreover, the institutional weakness of the Board strongly suggests that the Director will dominate the decision making process nominally entrusted to the Board.

In Indiana and Minnesota the board does not choose its executive director ${ }^{271}$ and thus cannot control him; thus there is no fear that he will simply be the tool of the board. Unfortunately, the preceding discussion suggests that the real problem underlying all these statutes is the reverse; making the director independent does

${ }^{269}$ Id. § 10-17.14 (1978).

${ }^{270}$ Id. \& 62.1-44.14 (1973). The California water pollution statute is similar. CAL. WATRR CODE $\S 13223$ (West 1971).

${ }^{271}$ IND. CODE ANN. $\S 13-1-1-3$ (Burns 1973) (technical secretary of air pollution control board named by secretary of state board of health); id. $\$ 13-1-3-3$ (technical secretary of stream pollution control board named by secretary of state board of health); id. $\S 13-7-2-2$ (technical secretary of environmental management board designated ex officio by statute); Minn. StAT. ANN. \$ 116.03(1)(a) (West Supp. 1979) (director appointed by Governor). 
nothing to reduce the dependence of the nominally sovereign board upon him.

\section{The Executive Department and Nonadvisory Board}

In contrast to the provisions just discussed, in which in theory the executive director is the agent of an all-powerful board, the more common pattern is to divide authority for pollution control between an executive department and an independent board.

Idaho, for example, has vested all rulemaking and adjudicatory powers in the Board of Health and Welfare, composed of seven members who serve four-year terms and are removable only for cause. ${ }^{272}$ Executive powers, on the other hand, including the authority to prosecute complaints before the Board, are entrusted to the Director of the Department of Health and Welfare, who serves at the Governor's pleasure. ${ }^{273}$

Thus the Idaho statute carefully separates the prosecutor from the judge as a matter of theory. Yet a closer look at the Idaho provisions raises serious doubts whether the ostensible separation can actually be maintained in practice. The Idaho Board, like the Virginia boards, is made up of part-time volunteers: its members are to receive minimal per diem compensation and expenses when "in the actual performance of duties."274 Members who are not paid to study the cases they are supposed to decide can hardly be expected to render an informed, independent judgment.

The Idaho pattern is followed in several other states, but the variations are considerable. In Wyoming, for example, the Department of Environmental Quality issues permits, grants variances, and utters cease-and-desist orders; divisional administrators are to recommend regulations to its director. ${ }^{275}$ Yet the "independent" Environmental Quality Council has the power to review department actions on permits, variances, and cease-and-desist orders, and the statute's repeated use of the phrase "the council finds" suggests that it is not bound to give any deference to the Department's findings. ${ }^{276}$ Moreover, no regulation becomes law without

272 IDAно CoDE § 39-107(1)-(2) (Supp. 1979).

273 Id. § 39-104 (1977). 1980).

974 Members receive $\$ 50$ a day and travel expenses. Id. \$§ 39-107(3), 59-509(h) (Supp.

${ }^{978}$ Wyo. STAT. $\$ \S 35-11-104$ to -110 (1977).

276 Id. $\$ \S 35-11-111$ to $-112,-601,-701,-801,-802$. 
Council approval. ${ }^{277}$ In short, the Council has ultimate rulemaking and adjudicating authority, just as in Idaho; but as in Idaho, Council members receive only a trivial per diem allowance and expenses, ${ }^{278}$ so its independence may be largely imaginary.

In Oregon a five-member commission adopts regulations, grants variances, and holds hearings to determine the imposition of civil penalties, ${ }^{279}$ while an "executive-administrative" Department of Environmental Quality is directed to "seek enforcement."280 Again the Commission is essentially unpaid, receiving $\$ 30$ per day of actual work plus expenses; ${ }^{281}$ it would be surprising if such a body could hold its own. Moreover, even the nominal separation of functions in Oregon leaves much to be desired. For one thing, the Department is empowered to "commence enforcement proceedings"282 under the state Administrative Procedure Act, ${ }^{283}$ which does not require so much as an independent hearing examiner, and to render a decision upon its own complaint. ${ }^{284}$ For another, the Commission appoints and removes the Director of the Department at pleasure,"288 it has power "to establish the policies for the operation of the department; ${ }^{286}$ and in everything it does the Department is "[s]ubject to policy direction by the commission." spite the statutory terminology, the differences between Oregon's system and the executive-director programs discussed in the preceding section are slim indeed.

In other states the role of the board or commission is more attenuated. In Delaware the secretary of an executive department adopts regulations, prosecutes and rules upon complaints, and grants permits and variances. ${ }^{288}$ The sole function of the board (which is paid only expenses ${ }^{289}$ ) is to entertain appeals by persons "substantially affected by an action of the secretary."290 The stat-

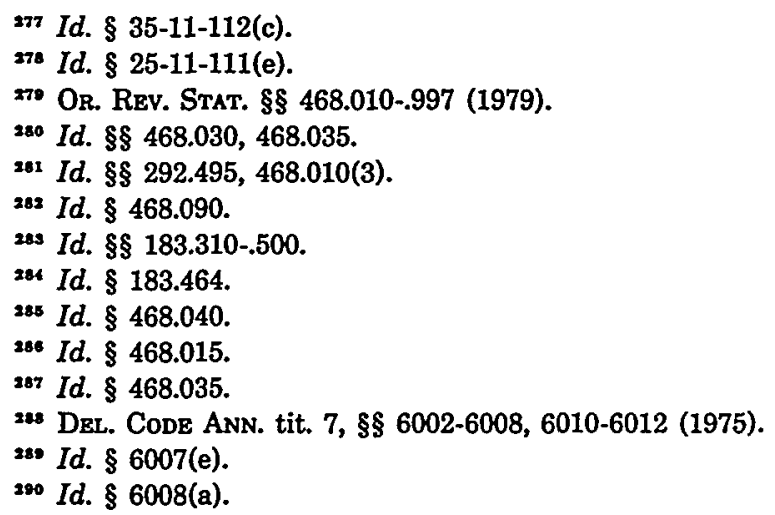


ute does not answer the crucial question whether the board's review is to be de novo. De novo review by an effective independent board would substantially ameliorate the initial combination of prosecutor and judge in the secretary, but even if the Delaware board is not expected to defer to any reasonable findings by the secretary, its part-time and poorly compensated nature seems likely to render it less than effective.

In Vermont there is not even a pretense of separating prosector from judge. The secretary of the executive agency has nearly all the functions of his Delaware counterpart, ${ }^{291}$ and the five-member board of amateurs ${ }^{282}$ has only the power to grant variances. ${ }^{293}$

\section{Board Member Qualifications}

The Idaho statute is very general in prescribing the qualifications of Board members. They are to be "chosen with due regard to their knowledge and interest in environmental protection and health," and no more than four of the seven may be of the same political party. ${ }^{204}$ Many statutes are much more specific. It is common, for example, to require that one member be a physician, or an engineer, or an attorney. ${ }^{295}$ Each of these disciplines obviously has something to contribute to the work of the board-the doctor understands some of the effects of pollution, the engineer something about control devices, the lawyer something about the legal rules. Just as obviously, however, people with other professions, such as ichthyology, or interested citizens with no expertise at all, may have something to contribute; the urge to require particular skills risks disqualifying the candidate for a particular vacancy who has the most to offer. The limit on the number of members from one political party, while an understandable precaution against cronyism, is subject to the same criticism.

Professional and political requirements are not the only types

291 VT. Stat. AnN. tit. 10, § 554 (1973).

${ }_{202}$ Id. $\$$ 553(b) (Supp. 1980). The board is to be composed of a lawyer, a manufacturer, an engineer, a businessman, and a member of the general public, none of whom may be employed by the state in any other capacity.

${ }^{203}$ Id. § 561 (1973).

294 IDAHO CODE $\S 39-107(1)$ (Supp. 1980).

295 E.g., OHIo Rev. Code ANN. $§ 3745.02$ (Page Supp. 1980) ("Each member shall have extensive experience in pollution control and abatement technology, ecology, public health, environmental law, economics of natural resource development, or related fields. At least one shall be an attorney."); VT. STAT. ANN. tit. 10, § 553(b) (Supp. 1980) (board must include lawyer, manufacturer, engineer, businessman, and representative of public). 
of qualifications imposed on board membership. Arizona's Water Quality Control Council, for example, is composed partly of the following people or their delegates: the director of the department of health services; members of the state game and fish, oil and gas conservation, and water commissions; the state land commissioner; and the dean of the state university agricultural college. ${ }^{296}$ In addition, the Governor is to appoint seven members, at least one of whom must come from each congressional district and:

one shall be appointed from the utility industry, one from the livestock industry, one from the forest products industry, one from the mining industry, one shall be appointed to represent the league of cities and towns and two shall be appointed from irrigation districts or water user associations. At least one of the foregoing shall be a civil engineer registered in Arizona. ${ }^{287}$

Two distinct principles of selection are exemplified by the Arizona statute. The first is the presence of officials of various executive branch agencies. New Mexico has carried this idea even further; its Water Quality Control Commission is made up almost entirely of executive officials. ${ }^{288}$ One evident goal of this approach is to facilitate coordination of executive policy on environmental matters by creating what is in effect a subcabinet to dispose of them. Another advantage is that ex officio members can devote substantial time to their pollution control tasks at government expense, which makes for a stronger board. The major disadvantage is that dominance of the executive in an adjudicatory body effectively undermines the separation of prosecutor from judge that was the primary apparent virtue justifying a separate board. Even when executive members are in a minority, as in Arizona, the separation is inadequate to satisfy ordinary notions of fair play: we do not put the United States Attorney on a panel of the Court of Appeals.

The second principle of selection found in the Arizona law is that the board should be broadly representative of the interest

29 ARIz. Rev. Stat. ANN. § 36-1853 (1974).

207 Id. \& 36-1853(7).

298 N.M. STAT. ANN. § 74-6-3 (1979) (commission consists of representatives of the environmental improvement division of the health and environment department, the game and fish department, the state engineer, the state park and recreation commission, the agriculture department, the natural resources conservation commission, the bureau of mines, the state engineer's office, and a lone representative of the public). 
groups affected by the pollution control program. Not only are specified polluting groups, from utilities to farmers to municipal governments, entitled to a voice, but many of the state government members also seem likely to view their role as that of spokesman for assorted interests their parent agencies represent. Representative government is a concept most Americans believe in, and big corporations may be able to finance released time to permit meaningful member participation. A glance at the Arizona list, however, gives cause for concern that the council may not come anywhere near reflecting the composition of the affected population. To state the matter more baldly, Arizona has placed the pollution control program in the hands of the polluters.

Other states have attempted to create more balanced combinations. In Tennessee, for example, three government representatives-one representative of the "public-at-large," one representative of conservation interests, one municipal representative, and one industrial representative-comprise the water quality control board. ${ }^{299}$ "No member shall be appointed unless at the time of his appointment he or his employer is in compliance with the provisions of [the Water Quality Control Act] as certified by the commissioner"; 300 and only "[t]hose members of the board who do not receive, or during the previous two (2) years have not received a significant portion of their income directly or indirectly from permit holders or applicants for a permit shall constitute a permit hearing panel.",301

Nevertheless, the danger remains that no board with a membership small enough to be able to function as a coherent administrative body is likely to contain representatives of every affected interest. More fundamentally, the effort to create a representative agency seems contrary to one of the basic reasons legislatures delegate rulemaking power to begin with-the desire for decision making based not on political power but on an objective search for the public good. If pollution standards are to be set on a representative basis, they should be set by a truly representative body: the elected state legislature.

The Pennsylvania Environmental Quality Board, which has rulemaking powers, has an unusual membership component. It consists of twelve ex officio members, five members of the citizens'

209 Tenn. Code Ann. $\S 70-327$ (a) (Supp. 1979).

${ }^{300} \mathrm{Id}$.

${ }^{\text {so1 }}$ Id. § 70-327(b). 
advisory council, and four members of the General Assembly. ${ }^{302}$ The addition of legislators seems superficially attractive as a means of legislative control over the essentially legislative business of rulemaking. But if constitutional provisions for separation of powers retain any meaning, it must give pause that executive and legislative officials share the responsibility for a single task under this system.

\section{E. State, Local, and Regional Authority}

Most state pollution control programs today are statewide in effect. Many of the relevant statutes make no mention of local powers; $;^{303}$ most of the others specifically permit local ordinances to be enacted as long as they are not inconsistent with the state program. ${ }^{304}$

In rare instances, "consistency" requires a perfect match, as in West Virginia, where the Attorney General ruled that local ordinances must be neither more nor less strict than state regulations. $^{305}$ This requirement allows local governments to participate in enforcement, but it denies them all ability to set standards to protect their inhabitants. Connecticut's provision is more typical: local ordinances are permissible if no less strict than state law. ${ }^{\mathbf{3 0}}$ Some states take an intermediate position, reflecting the potential conflict between legitimate local interests and overall state needs. In Virginia, for example, local ordinances are subject to approval by the state authority; ${ }^{307}$ in Florida the state administration may preempt control over certain sources. ${ }^{308}$ Thus local desire for stricter control may normally be accommodated, but parochial interests will not be allowed to prevent the location of necessary waste-disposal facilities everywhere in the State.

A few states still leave certain pollution matters largely or entirely to local governments. In New Mexico, for instance, the statute requires local governments in "A class counties" to establish

${ }^{302}$ Pa. Stat. AnN. tit. 71, § 180-1 (Purdon Supp. 1980).

sos See, e.g., Ky. REv. StAT. $\$ \S 224.005-.520$ (1977 \& Supp. 1978); Miss. Code AnN. $\S \S 49-17-1$ to -43 (1973 \& Supp. 1979); VT. STAT. ANN. tit. 10, §§ 1251-1283 (1973 \& Supp. 1980) (water program).

sor E.g., Colo. Rev. Stat. § 25-7-128 (Supp. 1979); TEnn. Code Ann. § 53-3426 (Supp. 1979); UTah Code ANN. \& 26-24-17 (1976).

sos Opinion of Mar. 30, 1972, reprinted in W. VA. CoDE $\S 16-20-5$ app. (1979).

sos Conn. Gen. Stat. Ann. § 19-520a (West 1977).

so7 VA. CODE § 10-17.30 (1978).

so8 Fla. Stat. AnN. \$ 430.182 (West 1973 \& Supp. 1980). 
programs to enforce the state statute by means of ordinances required to be at least as strict as state regulations. State jurisdiction does not extend to areas that have complied with this directive, except in case of "any act or failure to act" by the local government itself. If a local government fails to prosecute a violator, the state agency clearly can prosecute the local government itself for its inaction; whether the state may also proceed directly against the violator, which would have the advantage of curing the violation, is not clear from the words of the statute. ${ }^{309}$

Arizona appears to leave even more to local control. A state air pollution board and department are to exercise "jurisdiction and control" over "major sources," publicly owned sources, motor vehicles, and other "portable" sources. ${ }^{310}$ Everything else is within the ken of county or multi-county regions subject to local control; but their regulations may not be less stringent than comparable state requirements. ${ }^{311} \mathrm{~A}$ further provision authorizes the state to take over the functions of the local districts, but without specifying the grounds on which such action may be taken. ${ }^{322}$ Apparently this permits the state to negate the flat statutory insistence that, except for the specified sources, "jurisdiction and control of air pollution shall be by the county or multi-county air quality control region." 113

A few states create their own institutions to handle pollution control on a local basis, rather than entrusting that function to local government. The most intricate plan of this sort is found in California. Simply put, the California air pollution control program is overseen by a state board that adopts air quality standards for each region and serves as a backup enforcement mechanism. Regions are designated, largely by statute, as control districts, and district boards are appointed in a multitude of ways by local officials. If more than one district is located in a single air basin, a basin-wide council with rulemaking power is created. The state board has no financial control over districts, because funds are raised through additions to local property taxes. ${ }^{314}$ California's

309 N.M. Stat. AnN. § 74-2-4 (1979).

sio ARiz. REv. Stat. AnN. § 36-1706(A) (1974).

s11 Id. § 36-779.

s12 Id. § 36-1706(B).

s13 Id.

344 CaL. Health \& SapeTy Code $\S \S 39000-39108,40000-40865$ (West 1979 \& Supp. 1980). 
water pollution control program operates in much the same way. ${ }^{315}$

Regionalization is evidently an attempt to preserve local autonomy and to allow for varying local needs. Its costs include the multiplication of bureaucracies, the dispersion of qualified personnel, and the risk of abdication of state responsibility for protecting the public.

\section{Conclusion}

The details of the pollution laws vary greatly from state to state; no uniform statute has found widespread favor in this field. Yet the fundamentals of the program are strikingly similar nearly everywhere. The basic pattern is to delegate broad rulemaking power to an administrative agency, with enforcement through administrative permits and orders, injunctions, and judicial or administrative penalties, and commonly with the safety valve of administrative variances for cases of special hardship.

Some of the deviations from this pattern appear to limit significantly the effectiveness or appropriateness of the program. Some states are too grudging in their delegations of rulemaking authority; some lack a formal mechanism for dealing with hardship cases or an adequate permit system; some provide penalties too small to deter. In general, however, the statutory authority is basically sufficient; whether a state's control efforts are satisfactory is essentially within the control of the administering agency. Perhaps the most disturbing aspect of most state programs is the lack of effective separation between prosecutor and judge, which in my opinion is only glossed over, not corrected, by the vesting of adjudicatory powers in an unpaid citizen board. 